Utah State University

DigitalCommons@USU

$12-2021$

\title{
Injection of lodoacetic Acid into Pre-Rigor Bovine Muscle Simulates Dark Cutting Conditions
}

Jared Forrest Buhler

Utah State University

Follow this and additional works at: https://digitalcommons.usu.edu/etd

Part of the Food Science Commons

\section{Recommended Citation}

Buhler, Jared Forrest, "Injection of lodoacetic Acid into Pre-Rigor Bovine Muscle Simulates Dark Cutting Conditions" (2021). All Graduate Theses and Dissertations. 8236.

https://digitalcommons.usu.edu/etd/8236

This Thesis is brought to you for free and open access by the Graduate Studies at DigitalCommons@USU. It has been accepted for inclusion in All Graduate Theses and Dissertations by an authorized administrator of DigitalCommons@USU. For more information, please contact digitalcommons@usu.edu.

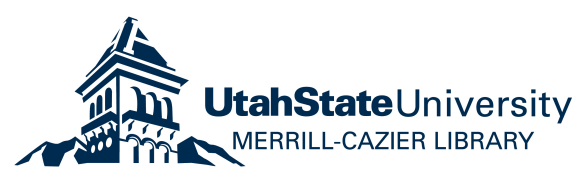




\title{
INJECTION OF IODOACETIC ACID INTO PRE-RIGOR BOVINE MUSCLE SIMULATES DARK CUTTING CONDITIONS
}

\author{
by \\ Jared Forrest Buhler \\ A thesis submitted in partial fulfillment \\ of the requirements for the degree \\ of \\ MASTER OF SCIENCE \\ in
}

Food Sciences

Approved:

Sulaiman K. Matarneh, Ph.D.

Kara J. Thornton-Kurth, Ph.D.

Major Professor

Committee Member

Robert Ward, Ph.D.

Marie Walsh, Ph.D.

Committee Member

Committee Member

D. Richard Cutler, Ph.D.

Interim Vice Provost of Graduate Studies

UTAH STATE UNIVERSITY

Logan, Utah 
(C) Jared Buhler 2021

All Rights Reserved 


\author{
ABSTRACT \\ Injection Of Iodoacetic Acid Into Pre-Rigor Bovine Muscle Simulates Dark Cutting Conditions \\ by \\ Jared Buhler, Master of Science \\ Utah State University, 2021
}

Major Professor: Dr. Sulaiman K. Matarneh

Department: Nutrition, Dietetics, and Food Sciences

The purpose of this study was to develop an in situ model for dark cutting beef. Iodoacetic acid (IAA) was injected at different concentrations $(0,0.625,1.25,2.5,3.75,5$, or $10 \mu \mathrm{mol} / \mathrm{g}$ of muscle) into pre-rigor bovine longissimus thoracis et lumborum (LTL) muscle samples, and $\mathrm{pH}$ and color were evaluated over a $48 \mathrm{~h}$ period. Injection of IAA blunted muscle $\mathrm{pH}$ decline and lowered $(P \leq$ 0.05) lightness $\left(\mathrm{L}^{*}\right)$, redness $\left(\mathrm{a}^{*}\right)$, and yellowness $\left(\mathrm{b}^{*}\right)$ values in a concentration dependent fashion. In a follow-up study, LTL muscle samples were injected with $5 \mu$ mol IAA/g of muscle to test whether IAA maintains its effect over a $336 \mathrm{~h}$ post-mortem storage period. In addition to inhibiting $\mathrm{pH}$ decline and decreasing color values, IAA increased $(P \leq 0.05)$ LTL muscle water holding capacity (WHC) and firmness throughout the $336 \mathrm{~h}$ post-mortem storage period. Collectively, these data suggest that pre-rigor injection of IAA generates beef with dark cuttinglike characteristics.

(50 pages) 


\section{PUBLIC ABSTRACT}

Injection Of Iodoacetic Acid Into Pre-Rigor Bovine Muscle Simulates Dark Cutting Conditions Jared Buhler

Following the harvest of an animal, muscle will continue to produce energy in an attempt to stay alive, primarily through the pathway of glycolysis. This occurs in the form of anaerobic (oxygenfree) metabolism of glucose and glycogen, which causes the meat to acidify. This acidification process is important for proper meat quality development and when insufficient glycolysis occurs it can cause a meat defect known as dark cutting. This defect causes the color of the muscle to become very dark, increases the water-holding capacity of the meat, and causes it to feel firm and dry on the surface because the water is held tightly within. This defect usually occurs when the animal is stressed prior to harvest, causing the animal to deplete glycogen stores and limiting the glycolysis that can occur after harvest. Fortunately, this defect rarely occurs in the US, but it occurs frequently in many other parts of the world. Consequently, US-based researchers are often interested in studying the properties of dark cutting meat, but are often unable to do so because they cannot obtain dark cutting samples. Therefore, the objective of this research was to develop a model to simulate dark cutting meat. This was achieved by injecting iodoacetic acid (an inhibitor of glycolysis) into the muscle immediately after the harvest of the animal to mimic the effects of glycogen depletion. Color, water-holding capacity, and firmness of the meat were then tested to ensure that the properties of the meat were similar to those of naturally-occurring dark cutting meat. The results suggested that injection of iodoacetic acid produced meat with dark cutting characteristics and this model may be used to study dark cutting meat when naturally-occurring samples are not available. 
CONTENTS

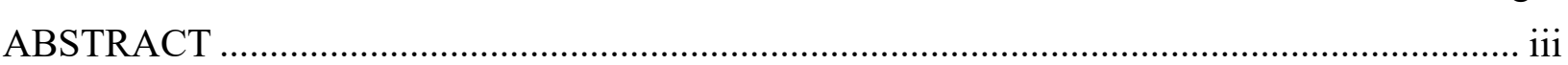

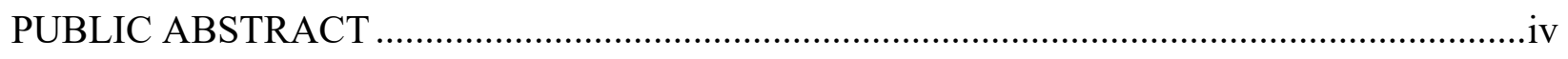

LIST OF TABLES AND FIGURES .......................................................................... vii

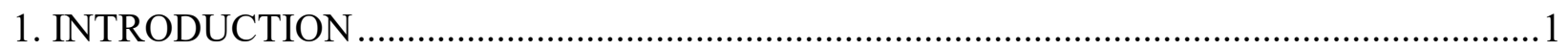

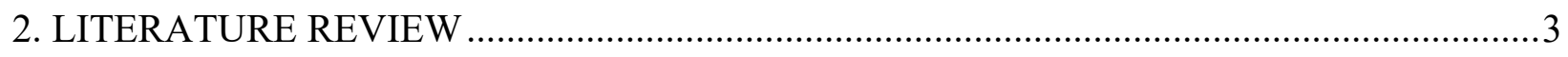

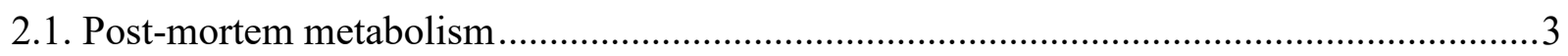

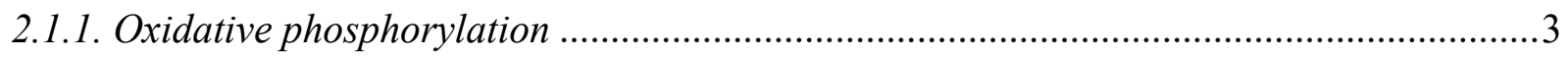

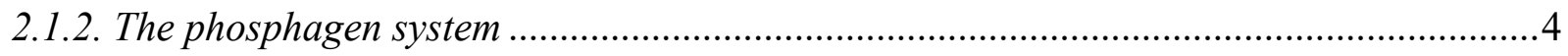

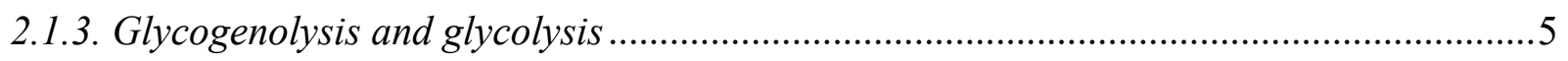

2.3. Factors controlling the rate of post-mortem $\mathrm{pH}$ decline ............................................ 8

2.4. Factors controlling the extent of post-mortem $\mathrm{pH}$ decline .......................................... 10

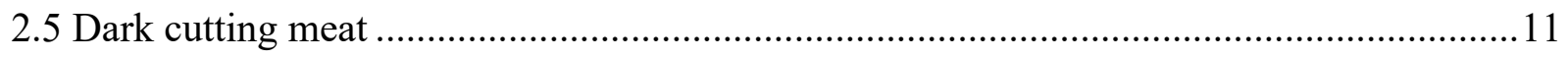

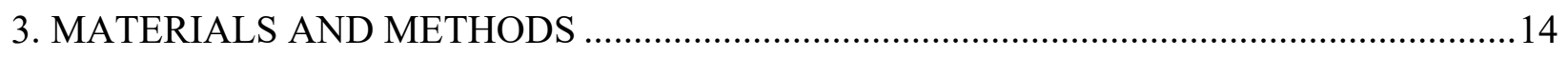

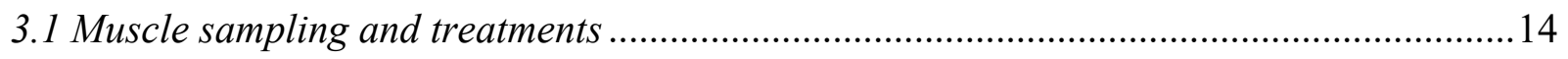

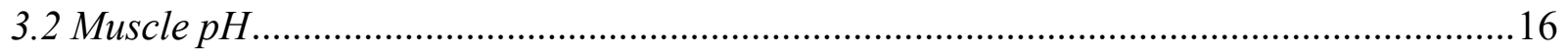

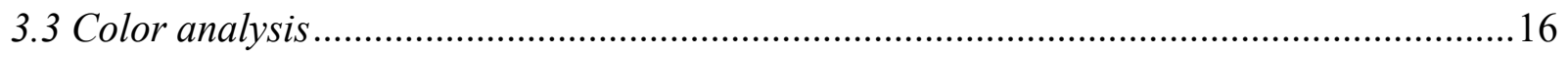

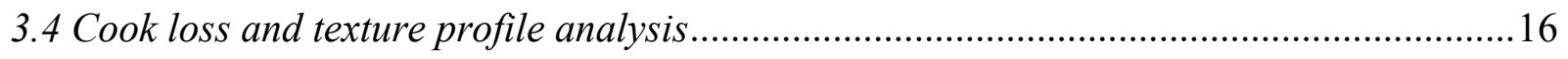

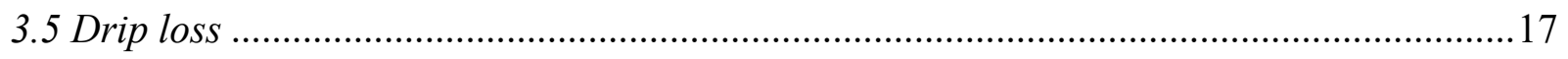

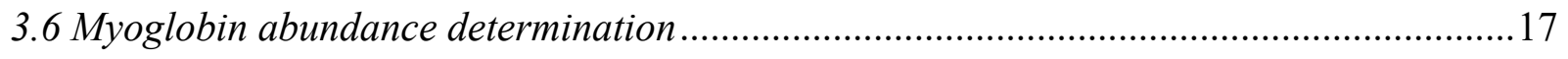

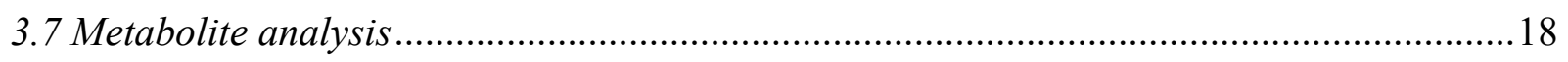

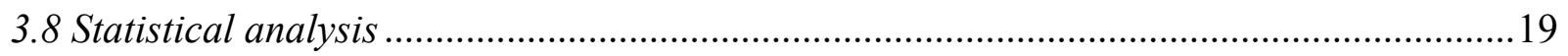

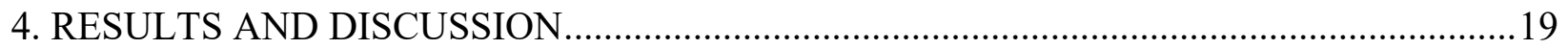

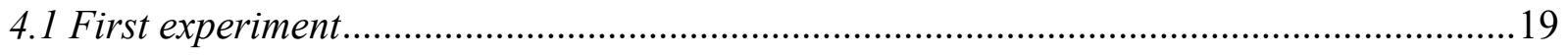


4.1.1. Effect of different concentrations of IAA on the pH of LTL muscle ..........................20

4.1.2. Effect of different concentrations of IAA on the color of LTL muscle ........................22

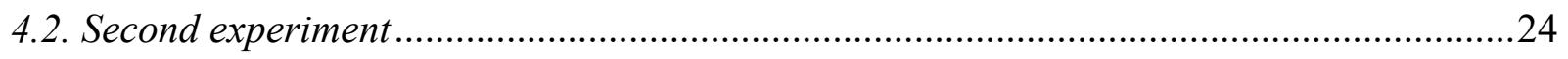

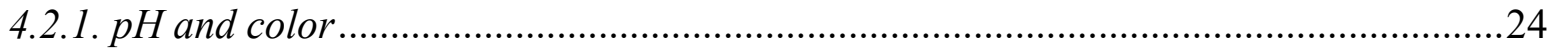

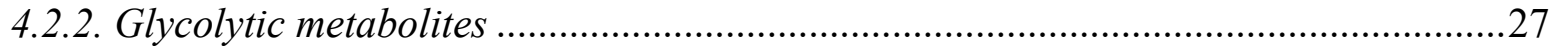

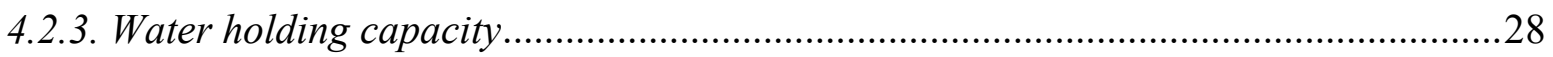

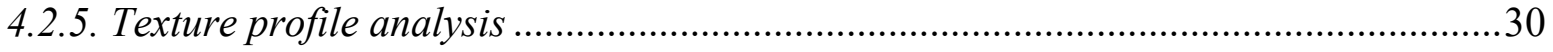

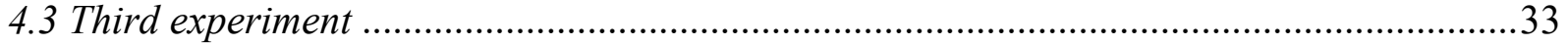

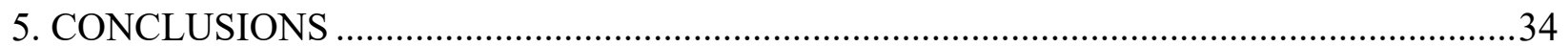

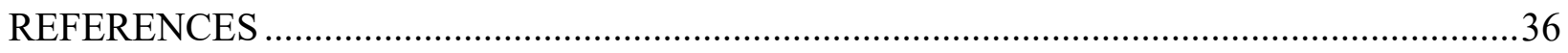

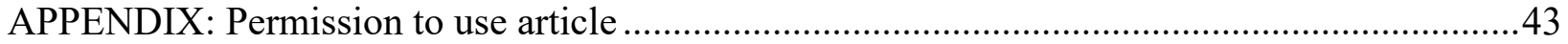




\section{LIST OF TABLES AND FIGURES}

Page

Table 1. Effect of different concentrations of iodoacetic acid on $\mathrm{pH}, \mathrm{L}^{*}, \mathrm{a}^{*}$, and $\mathrm{b}^{*} \ldots \ldots \ldots \ldots .21$

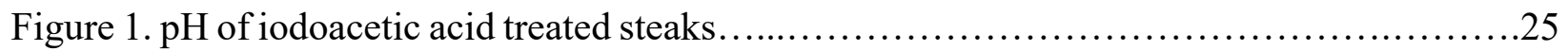

Figure 2. Image and $L^{*}, a^{*}, b^{*}$ values of iodoacetic acid treated steaks.......................26

Figure 3. Glycolytic metabolite profile of iodoacetic acid treated steaks.......................28

Figure 4. Water-holding capacity of treated steaks demonstrated by drip loss and cook loss.......29

Figure 5. Myoglobin abundance as measured by western blot.............................30

Figure 6. Texture profile analysis of raw steaks.........................................

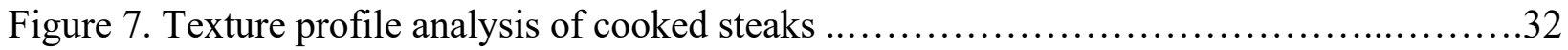

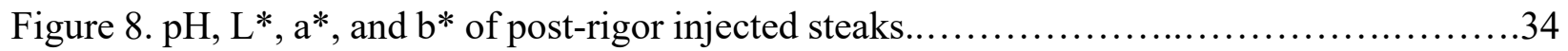




\section{INTRODUCTION ${ }^{1}$}

During the conversion of muscle to meat, glycogen is degraded through glycogenolysis and glycolysis to yield lactate and ATP; the subsequent hydrolysis of ATP generates hydrogen ions $\left(\mathrm{H}^{+}\right)$that accumulate in the muscle, leading to its acidification (Matarneh, England, Scheffler, \& Gerrard, 2017). The extent of post-mortem $\mathrm{pH}$ decline is one of the most important factors affecting the development of meat quality attributes. In general, $\mathrm{pH}$ of post-mortem muscle drops from approximately 7.2 to an ultimate $\mathrm{pH}$ around 5.6. However, post-mortem muscle may exhibit limited $\mathrm{pH}$ decline $(\mathrm{pH}>6)$, which usually leads to the development of the dark, firm, and dry (DFD) meat condition, also known as dark cutting in beef (Hall, Latschar, \& Mackintosh, 1944). Dark cutting meat is characterized as having an abnormally dark color, firm texture, and dry, sticky feel. This defect is usually associated with limited muscle glycogen reserves owing to prolonged ante-mortem stress, thus causing early termination of post-mortem metabolism (England, Matarneh, Scheffler, \& Gerrard, 2017; Matarneh et al., 2017).

As the name implies, dark cutting meat is unsavory from a visual perspective, which often results in its rejection by consumers (Ponnampalam et al., 2017). Additionally, this defective meat is more susceptible to microbial spoilage due to its elevated $\mathrm{pH}$ and water content (Ramanathan, Kiyimba, Gonzalez, Mafi, \& DeSilva, 2020; Shange, Gouws, \& Hoffman, 2019). These undesirable traits are causes for downgrading of dark cutters, resulting in large financial losses for the meat industry worldwide. For instance, it is estimated that the Australian beef industry loses about AU \$36 million each year due to dark cutting carcasses (Ponnampalam et al., 2017). However, the incidence of dark cutters is relatively low in the US at 1.9\% (Boykin et al., 2017),

${ }^{1}$ Meat Science. Injection of iodoacetic acid into pre-rigor bovine muscle simulates dark cutting conditions. Volume 176, June 2021, 108486. Jared F. Buhler, David S. Dang, Chandler D. Stafford, Natalie E. Keele, Abigail N. Esco, Kara J. Thornton, Daren P. Cornforth, Sulaiman K. Matarneh. (original copyright notice as given in the publication in which the material was originally published) "With permission from Elsevier." 
but is more prevalent in other countries such as Brazil (up to 5\%) (Rosa et al., 2016), Australia and China (up to 10\%) (Ponnampalam et al., 2017; Ijaz et al., 2020). The low incidence rate of dark cutters in the US makes it challenging for US-based researchers to find dark cutting samples for their research. Moreover, dark cutting often occurs in clusters (Ponnampalam et al., 2017), with significantly less incidence in certain months of the year (Tarrant \& Sherington, 1980). Due to the difficulty of obtaining dark cutting samples, researchers have attempted to induce dark cutting conditions by injecting animals with epinephrine before harvest in order to deplete muscle glycogen (Penny, Voyle, \& Lawrie, 1963; Tarrant \& Sherington, 1980; Watanabe, Daly, \& Devine, 1996). However, the effectiveness of epinephrine injection in simulating dark cutting conditions is muscle dependent (Tarrant $\&$ Sherington, 1980), and may be difficult to be approved by an animal care and use committee. Thus, alternative methods should be developed to simulate dark cutting characteristics in order to facilitate future dark cutting related research.

Iodoacetic acid (IAA) is a cell permeable, active site-directed inhibitor of glyceraldehyde-3phosphate dehydrogenase (GAPDH), the enzyme that catalyzes the sixth step of glycolysis (Foxall, Brindle, Campbell, \& Simpson, 1984; Mulvany, 1975). IAA has long been utilized in the area of meat science to inhibit glycolysis and $\mathrm{pH}$ decline in muscle homogenates, which allows for measuring post-mortem muscle $\mathrm{pH}$ at specific time points (Bendall, 1973). Additionally, IAA has been shown effective in inhibiting post-mortem metabolism when injected intravenously prior to harvest (De Fremery, 1966). Yet, this method entails many of the same issues associated with epinephrine injection. Therefore, the objective of this study was to develop an in situ model of dark cutting conditions through injecting IAA into pre-rigor bovine muscle samples. We hypothesized that pre-rigor injection of IAA would inhibit anaerobic glycolysis and result in meat with high ultimate $\mathrm{pH}$ and characteristics similar to dark cutting beef. 


\section{LITERATURE REVIEW}

\subsection{Post-mortem metabolism}

Following the slaughter of an animal, several biochemical changes occur in the muscle that leads to its transformation into meat. These changes are essential to imparting a unique set of attributes on fresh meat, including its color, water holding capacity (WHC), and textural properties. Among these changes, the decline in $\mathrm{pH}$ resulting from post-mortem metabolism is the most significant. Even after exsanguination, energy metabolism pathways continue to function in the dying tissue in a futile effort to maintain ATP homeostasis. These metabolic pathways include mitochondrial oxidative phosphorylation, the phosphagen system, and anaerobic glycolysis.

\subsubsection{Oxidative phosphorylation}

Mitochondria are known for their essential role in ATP production through cellular respiration. Substrates such as pyruvate and fatty acids are transported into the mitochondrial matrix where they are converted to acetyl-CoA. Citrate synthase catalyzes the condensation of acetyl-CoA and oxaloacetate to citrate, which is sequentially metabolized through the tricarboxylic acid (TCA) cycle $\left(2\right.$ acetyl groups $+6 \mathrm{NAD}^{+}+2 \mathrm{FAD}+2 \mathrm{ADP}+2 \mathrm{P}_{\mathrm{i}} \rightarrow 4 \mathrm{CO}_{2}+6 \mathrm{NADH}+6 \mathrm{H}^{+}+2$ $\left.\mathrm{FADH}_{2}+2 \mathrm{ATP}\right)$. Electrons donated from $\mathrm{NADH}$ and $\mathrm{FADH}_{2}$ are then transported down the electron transport chain to drive ATP synthesis.

At the death of an animal, oxygen is no longer transported to the muscle, leaving it with diminishing oxygen availability. Because mitochondrial respiration is hindered by the lack of oxygen, mitochondria are often considered irrelevant to post-mortem metabolism. Yet, recent studies suggest that mitochondria may play a larger role than previously thought (England et al., 2018; Matarneh, Beline, de Luz e Silva, Shi, \& Gerrard, 2018a; Matarneh et al., 2017b; Matarneh, Yen, Bodmer, El-Kadi, \& Gerrard, 2021b; Scheffler, Matarneh, England, \& Gerrard, 2015) 
England et al. (2018) found that post-mortem muscle oxygen concentration is gradually depleted during the first two hours post-mortem, suggesting residual mitochondrial respiration. In support of this notion, Matarneh et al. (2021b) showed that mitochondria are capable of mobilizing part of the pyruvate generated through glycolysis in an in vitro model simulating post-mortem metabolism. Using the same in vitro model, it was shown that mitochondria can extend anaerobic metabolism by increasing the rate of ATP hydrolysis (Matarneh et al., 2018a).

\subsubsection{The phosphagen system}

While ATP is the primary energy currency of the cell, it is stored in a relatively low concentration in the muscle $(5-8 \mu \mathrm{mol} / \mathrm{g}$ of tissue), which is only sufficient for a few seconds of high energy demands (England et al., 2017). During the early post-mortem period, cellular ATP levels are maintained at or near ante-mortem levels by utilizing phosphocreatine. Phosphocreatine contains a high-energy phosphate bond that can be broken to supply the energy and inorganic phosphate required to phosphorylate ADP to ATP, in a reaction catalyzed by creatine kinase. However, the ability of phosphocreatine to maintain ATP levels is also limited, and as soon as phosphocreatine has been depleted, ADP begins to accumulate in post-mortem muscle (Matarneh et al., 2017a). The enzyme adenylate kinase is able to make use of this ADP by catalyzing the transfer of a phosphate group from one ADP to another to form ATP and AMP. To shift the equilibrium of this reaction toward the formation of ATP, AMP is removed from the product pool by the enzyme AMP deaminase, which irreversibly deaminates AMP to IMP. This reaction is beneficial in the short term because it increases the activity of adenylate kinase. At the same time, however, it reduces the total adenonucleotide pool (ATP, ADP, AMP) available for muscle metabolism postmortem (England, Matarneh, Scheffler, Wachet, \& Gerrard, 2015; Hamm, 1977). While the phosphagen system plays an important role in ATP homeostasis, its ability to maintain ATP 
concentrations is limited (Bogdanis, Nevill, Boobis, \& Lakomy, 1996). Therefore, another pathway is necessary to continue producing ATP when the phosphagen system has been exhausted.

\subsubsection{Glycogenolysis and glycolysis}

As post-mortem muscle attempts to maintain ante-mortem concentrations of ATP, glycogenolysis and glycolysis become the primary energy producing pathways (England et al., 2017). Glycogen is the storage macromolecule form of glucose, a highly branched polymer of glucose monomers bound with $\alpha-1,4$-glycosidic bonds and $\alpha-1-6$ bonds at branching points. Glycogen is broken down by glycogen phosphorylase and glycogen debranching enzymes to yield glucose-6-phosphate and glucose, which may then enter glycolysis to yield two pyruvate molecules, a net of three ATP, two $\mathrm{NADH}$, one $\mathrm{H}^{+}$, and two $\mathrm{H}_{2} \mathrm{O}$ molecules. In the absence of oxygen, cellular respiration is arrested, and pyruvate is converted to lactate by the enzyme lactate dehydrogenase (Pyruvate + NADH + $\mathrm{H}^{+} \leftrightarrow$ Lactate $+\mathrm{NAD}^{+}$). This reaction is essential to regenerate $\mathrm{NAD}^{+}$, allowing glycolysis to continue running under post-mortem anaerobic conditions. It is important to note that the lactate dehydrogenase reaction consumes one $\mathrm{H}^{+}$for each pyruvate converted to lactate, and thus, a net of one $\mathrm{H}^{+}$is consumed for each glucose molecule metabolized through anaerobic glycolysis. However, oxidation of glucose through glycolysis produces 3 ATP for each glucose molecule, and the hydrolysis of ATP by muscle ATPases releases $\mathrm{H}^{+}\left(\mathrm{ATP}+\mathrm{H}_{2} \mathrm{O} \rightarrow \mathrm{ADP}+\mathrm{Pi}+\mathrm{H}^{+}+\right.$energy). Therefore, the net $\mathrm{H}^{+}$production from the conversion of glucose to lactate coupled with ATP hydrolysis is $2 \mathrm{H}^{+}$per glucose molecule (Robergs, Ghiasvand, \& Parker, 2004). Due to the lack of circulation, these $\mathrm{H}^{+}$accumulate in post-mortem muscle, resulting in its acidification. During the post-mortem period, muscle $\mathrm{pH}$ gradually drops from 7.2 to a final (ultimate) $\mathrm{pH}$ of 5.5-5.7 in most meat species. This $\mathrm{pH}$ decline pattern is extremely important for proper meat quality development (Scheffler \& Gerrard, 2007). 


\section{2. $\mathrm{pH}$ and meat quality}

The rate and extent of post-mortem $\mathrm{pH}$ decline are among the most significant factors influencing the development of meat quality characteristics. Changes in $\mathrm{pH}$ strongly correlate with changes in meat color (Swatland, 2008), WHC (Bouton, Harris, \& Shorthose, 1971), and tenderness (Beltrán et al., 1997), and even small deviations from normal $\mathrm{pH}$ decline can negatively influence the characteristics of the meat.

The ability of meat to retain water is an important characteristic for both quality and economic reasons. Water loss from a meat product is detrimental to its juiciness after cooking, and any water loss prior to packaging is a financial loss for the industry. Water is a dipolar molecule and, therefore, is attracted to electrically charged groups such as proteins. Ultimate $\mathrm{pH}$ is a major determinant of meat WHC as it determines the ionization state of muscle proteins (den HertogMeischke, van Laack, \& Smulders, 1997). The average isoelectric point ( $\mathrm{p} I$ ) of major muscle proteins is achieved at $\mathrm{pH}$ 5.1-5.2 (Matarneh et al., 2017a). At this $\mathrm{pH}$, minimum charges are available for water to interact with, and thus, the meat has minimal WHC. On the other hand, moving away from the $\mathrm{p} I$ increases the net charge of muscle proteins as well as the ability to hold water. Additionally, as the net charge increases (negatively or positively), there are greater like charges. This causes a repulsion between muscle structures, thereby expanding the space within the muscle fiber and allowing it to hold more water (Purslow, Warner, Clarke, \& Hughes, 2020). In some cases, WHC may be impacted by an abnormally fast rate of $\mathrm{pH}$ decline as well, especially when this occurs while the carcass is still warm. This rapid decline in $\mathrm{pH}$ causes excessive protein denaturation, leading water to be expelled from the muscle fiber into the extracellular space (Huda, 2011). 
As one of the characteristics that the consumer can judge when making purchasing decisions, meat color is an important quality determinant of retail sale value (Suman \& Joseph, 2013). Meat color is highly correlated with $\mathrm{pH}$, in which meat with low $\mathrm{pH}$ has a lighter color than meat with high $\mathrm{pH}$ (Abril et al., 2001). As mentioned previously, $\mathrm{pH}$ has a significant impact on the WHC of meat, and it is largely through WHC that meat color is affected by ultimate $\mathrm{pH}$. WHC impacts meat color by changing how the muscle interacts with light (Hughes, Oiseth, Purslow, \& Warner, 2014). At low WHC, the muscle fiber size is reduced, which promotes light scattering and reflection (Purslow et al., 2020). Light scattering and reflection are also caused by protein denaturation that occurs as a result of rapid $\mathrm{pH}$ decline. In contrast, meat with high WHC has enlarged muscle fibers and minimal protein denaturation, which causes light to penetrate deeper and be absorbed (Swatland, 2008). Meat color is also determined by myoglobin content, which is the major meat pigment. Muscles with elevated myoglobin content tend to be darker in color and redder than muscles with little myoglobin content (Vestergaard, Oksbjerg, \& Henckel, 2000). As a water-soluble protein, myoglobin is lost during storage through purge and drip. Thus, WHC can impact the myoglobin content of the meat, as more myoglobin is retained in meat with high WHC (Mahmood et al., 2017; Çelen, Sögüt, Zorba, Demirulus, \& Tekeli, 2016).

Additionally, $\mathrm{pH}$ can impact the textural properties of both raw and cooked meat. In raw meat, firmness is positively correlated with $\mathrm{pH}$, where low $\mathrm{pH}$ meat is soft while high $\mathrm{pH}$ meat is firm. This phenomenon occurs due to the WHC of the meat; in meat with high WHC, the muscle is filled with water, causing it to feel firm to the touch (Hughes et al., 2014). pH can affect tenderness of cooked meat by influencing the activity of endogenous proteases during meat aging. Proteolysis of structural proteins within the muscle is often described as the main factor determining meat tenderness (Kemp, Sensky, Bardsley, Buttery, \& Parr, 2010), and the calpain 
protease system is usually considered the major contributor to post-mortem tenderization (Koohmaraie \& Geesink, 2006). Calpains are more active at higher $\mathrm{pH}$, and thus, high $\mathrm{pH}$ meat is often found to be more tender (Beltrán et al., 1997; Silva, Patarata, \& Martins, 1999).

\subsection{Factors controlling the rate of post-mortem $\mathrm{pH}$ decline}

While the rate of $\mathrm{pH}$ decline is influenced by a number of factors (Hamoen, Vollebregt, \& Van Der Sman, 2013), Scopes (1974) concluded that the rate of post-mortem pH decline is primarily dictated by the rate of ATP hydrolysis by muscle ATPases. The activity of muscle ATPases itself is generally enhanced with increasing muscle temperature and cytosolic calcium levels (Savell, Mueller, \& Baird, 2005). Therefore, meat harvesting facilities must tightly monitor temperature as a strategy to control the rate of $\mathrm{pH}$ decline, and thus meat quality (Hannula \& Puolanne, 2004). Insufficient cooling of the carcass may cause the rate of $\mathrm{pH}$ decline to accelerate and adversely influence the quality of the meat (Hammelman et al., 2003). In contrast, meat that is chilled quickly may exhibit "cold shortening," a phenomenon that occurs when the carcass reaches cold temperatures prior to rigor mortis (Locker \& Hagyard, 1963). At low temperature, the ability of the muscle to sequester calcium is impaired, causing a sharp increase in cytosolic calcium concentration. This causes severe muscle contraction, a rapid decline in $\mathrm{pH}$, and toughening of the meat (Savell et al., 2005).

Because post-mortem muscle acidification is driven by anaerobic glycolysis, the rate of $\mathrm{pH}$ decline reflects the intensity of post-mortem glycolysis. As such, the rate of $\mathrm{pH}$ decline tends to be faster in muscles with more glycolytic fibers compared to those containing more oxidative fibers (Matarneh et al., 2017a). The incentive to produce animals that grow faster and larger has caused an increased proportion of glycolytic muscle fibers in domesticated animals (Barbut et al., 2008). This has resulted in an increased rate of post-mortem $\mathrm{pH}$ decline and meat defects 
associated with it, particularly in pork and poultry (Wilson, 1990). One of these defects is pale, soft and exudative (PSE) meat, named for its excessively pale color, soft texture, and poor WHC. This defect occurs when the rate of $\mathrm{pH}$ decline is faster than normal, causing the meat to reach ultimate $\mathrm{pH}$ well before carcass cooling has occurred (Molette, Rémignon, \& Babilé, 2003). The rapid acidification at high temperature results in excessive protein denaturation, which drastically lowers the WHC of the muscle and changes its light scattering characteristics (Huda, 2011). PSE meat occurs most commonly in pork and has been associated with porcine stress syndrome, a condition analogous to human malignant hyperthermia (Louis, Galbrit, Remple, \& Mickelson, 1990). This syndrome occurs as a result of a genetic mutation in the ryanodine type 1 (RYR1) gene, which encodes the calcium-releasing channels in the muscle. RYR1 mutant pigs are unable to control cellular calcium levels under stressful conditions, which dramatically increases muscle contraction, increases body temperature, and occasionally causes death (Ball \& Johnson, 1993). While this unfortunate mutation was initially favored due to its enhancements of growth characteristics (Lockley, Bruce, Franklin, \& Bardsley, 1996), it has nearly been erradicated from herds through DNA testing, and does not account for the incidence of PSE pork anymore (Ritter et al., 2008). PSE meat may occur due to poor animal handling that causes acute stress to the animal immediately prior to harvest, improper cooling, or as a result of other genetic predispositions (Nonneman, Brown-Brandl, Jones, Wiedmann, \& Rohrer, 2012).

In contrast to pork and poultry, ruminant animals have a higher proportion of oxidative fibers, and consequently, their rate of $\mathrm{pH}$ decline tends to be slower. While this leaves ruminants animals less prone to PSE, their slow rate of post-mortem acidification may be detrimental to meat quality as well (Adeyemi \& Sazili, 2014). This can be mitigated by electrical stimulation, which is widely used in beef processing plants. Electrical stimulation accelerates the release of calcium, 
muscle contraction, and $\mathrm{pH}$ decline. This is particularly beneficial for reducing the incidence of cold shortening because it helps the carcass reach rigor mortis before cold temperatures are reached (Savell et al., 2005). Moreover, ruminants have more mitochondria, and recent evidence suggests that mitochondria play a role in modulating the rate of $\mathrm{pH}$ decline as well (Hudson, 2012; Matarneh et al., 2018a, 2021b). While the mechanisms involved remain somewhat unclear, this is likely caused by increased ATP hydrolysis through "mitochondrial treason," a phenomenon that occurs when ATP synthase runs in reverse and hydrolyzes ATP (Hudson, 2012; Matarneh et al., 2018a).

\subsection{Factors controlling the extent of post-mortem $\mathrm{pH}$ decline}

Despite the differences between species, the ultimate $\mathrm{pH}$ of all meat animals tends to fall into a similar range (5.5-5.7). This suggests that factors controlling the extent of $\mathrm{pH}$ decline are conserved across species. Perhaps the first determining factor for the extent of post-mortem metabolism is the amount of substrate present in the muscle at the time of harvest; if glycogen concentration is less than $53 \mu \mathrm{mol} / \mathrm{g}$ of muscle then substrate availability becomes a limiting factor (Henckel, Karlsson, Jensen, Oksbjerg, \& Petersen, 2002). When glycogen is not limiting, a combination of other factors terminates post-mortem glycolysis and stops $\mathrm{pH}$ decline. One of these factors is the activity of phosphofructokinase (PFK), the key regulatory enzyme of glycolysis. PFK controls the extent of $\mathrm{pH}$ decline as it begins to lose activity at $\mathrm{pH} 5.9$ and inactivates completely at pH 5.6 (England, Matarneh, Scheffler, Wachet, \& Gerrard, 2014), which brackets the ultimate $\mathrm{pH}$ of most meat species into a fairly consistent range around 5.6. In some cases, however, muscle $\mathrm{pH}$ may decline below 5.6 if more substrate passes PFK before inactivation (i.e., increased glycolytic flux). This is clearly evident in the AMPK $\gamma 3^{\mathrm{R} 200 \mathrm{Q}}$ mutant pigs, which often produce meat with extremely low ultimate $\mathrm{pH}(\mathrm{pH}<5.4)$. This is the cause of a meat defect known as "acid meat" that has characteristics similar to PSE meat (England et al., 2015; Matarneh, England, 
Scheffler, Oliver, \& Gerrard, 2015). Additionally, these pigs serve as an example of how buffering capacity can impact ultimate $\mathrm{pH}$, as muscle of $\mathrm{AMPK} \gamma 3^{\mathrm{R} 200 \mathrm{Q}}$ mutant pigs has decreased buffering capacity that allows it to reach a lower $\mathrm{pH}$ with less $\mathrm{H}^{+}$production (Matarneh et al., 2015). In contrast, there are cases where glycogen may not be limiting, but post-mortem metabolism terminates prematurely $(\mathrm{pH}>5.9)$. This occurs in chicken muscle because the PFK found in chicken is less active than other species (Matarneh et al., 2018b). Furthermore, muscles containing a high proportion of oxidative fibers may terminate glycolysis prematurely while PFK is still functioning because the oxidative fiber type promotes faster depletion of adenosine nucleotides (England et al., 2016). In the absence of adenosine nucleotides, glycolysis is inhibited as ATP is required for PFK while ADP is required for phosphoglycerate kinase and pyruvate kinase reactions. On the other hand, maintaining the adenosine nucleotide pool for a longer period postmortem through inhibiting AMP deaminase has been shown to extend post-mortem glycolysis and pH decline (England et al., 2015).

\subsection{Dark cutting meat}

Dark, firm, and dry is a meat defect that occurs when the ultimate $\mathrm{pH}$ stops at a higher than normal value $(\mathrm{pH}>6)$. DFD meat is most easily recognized by its abnormally dark color, and as such, the term "dark cutting" is used to describe DFD conditions in cattle. The high ultimate $\mathrm{pH}$ of dark cutting meat also increases its WHC, causing it to exude very little water and feel dry and firm to the touch. Dark cutting is generally considered a defect because the dark color reduces the retail sale value, and the elevated $\mathrm{pH}$ provides a more hospitable environment for microbial growth (Newton \& Gill, 1981).

Dark cutting is usually caused by the depletion of muscle glycogen prior to slaughter, which causes early termination of glycolysis due to lack of substrate (Matarneh, Silva, \& Gerrard, 
2021a). This is generally attributed to long-term ante-mortem stress such as inclement weather during transportation and holding, long travel times, rough handling processes, or mixing unfamiliar animals (Huda, 2011). These stressful events cause the release of catecholamines (epinephrine and norepinephrine) that stimulate glycogenolysis and lipolysis. When glycogen depletion occurs, insufficient lairage (time between transport and harvest) to restore glycogen can increase the risk of dark cutting. Replenishment of muscle glycogen is a slow process, especially for ruminants, as they absorb very little glucose from their gastrointestinal tract (Pethick et al., 1999). For this reason, ruminants tend to produce DFD meat more frequently than monogastric animals.

Although glycogen depletion is traditionally attributed to stress, there are other potential causes for low glycogen prior to slaughter (Ramanathan et al., 2020). In some cases, glycogen stores may be low due to feed restriction or a low energy diet, and consistently, glycogen concentrations are generally lower in grass-fed cattle than grain-fed cattle (Immonen, Ruusunen, Hissa, \& Puolanne, 2000). McKeith et al. (2016) found elevated abundance of mitochondria in dark cutting carcasses, and mitochondria from dark cutters were less efficient. Therefore, it was hypothesized that less energy-efficient mitochondria may consume more glycogen prior to the harvest of the animal and thus contribute to glycogen depletion. Moreover, there are factors other than $\mathrm{pH}$ that may contribute to dark-colored meat. For instance, grass-fed cattle typically produce beef with a darker color than their grain-fed counterparts, even when the $\mathrm{pH}$ is normal (Wicks et al., 2019). This is due to an increased proportion of oxidative muscle fibers that typically contain more myoglobin. Vestergaard et al. (2000) found that an increase in oxidative muscle fibers increases proportion of muscle pigmentation, and this contributed to darker meat color. It is important to note that animals with a higher proportion of oxidative muscle fibers were darker in 
color, but were still not classified as dark cutters. However, even a slight elevation in $\mathrm{pH}$ may cause their meat to classify as dark cutting; as the meat is already dark, any further darkening may push the meat into dark cutting classification (Mahmood et al., 2017). The inverse of this is seen in chicken, which typically has higher ultimate $\mathrm{pH}$ than other species but appears light in color because it contains so little pigmentation (Matarneh et al., 2018b; Qiao, Fletcher, Smith, \& Northcutt, 2001).

Beyond the dark color and spoilage concerns, dark cutting beef is comparable in quality to normal beef. Taste panel evaluation of dark cutting beef often finds that it is equally acceptable when compared to normal beef, but the flavor is sometimes reported to be different (Holdstock et al., 2014; Viljoen, De Kock, \& Webb, 2002). Instrumental analysis of dark cutting beef often finds it is more tender than normal beef (Franco et al., 2015; Silva et al., 1999), and therefore, dark cutting does not necessarily need to be thought of as a defect.

As a result of optimized handling procedures, the incidence rate of dark cutting is low within the US at approximately 1.9\% (Boykin et al., 2017). Unfortunately, dark cutting occurs more frequently in many other parts of the world, such as Brazil (up to 5\%) (Rosa et al., 2016), Australia and China (up to 10\%) (Ponnampalam et al., 2017; Ijaz et al., 2020). Accordingly, researchers put appreciable effort into studying the properties of dark cutting meat and developing methods to improve its properties, even within the US. However, due to the low incidence rate, it is often difficult for US-based researchers to obtain dark cutting samples.

Objective: to create a model that simulates the dark cutting condition to allow researchers to study dark cutting when samples are unavailable.

Hypothesis: Pre-rigor injection of IAA inhibits anaerobic glycolysis and results in meat with high ultimate $\mathrm{pH}$ and characteristics similar to dark cutting beef. 


\section{MATERIALS AND METHODS}

\subsection{Muscle sampling and treatments}

All cattle used in this study were raised at the Utah State University South Farm under the same feeding and management conditions. Five young steers (12-13 months old; $327.1 \pm 5.6 \mathrm{~kg}$ live weight) of similar genetic background were harvested at the Utah State University harvest facility according to standard commercial practices and USDA inspection guidelines. Within 30 min of exsanguination, the longissimus thoracis et lumborum (LTL) muscle was excised from the left side of the carcass and fabricated into seven $2.5-\mathrm{cm}$ steaks. Steaks were weighed and then randomly injected with one of six different IAA solutions $(200,100,75,50,25,12.5 \mathrm{mM}$; adjusted to $\mathrm{pH}$ 7.0 with $1 \mathrm{M} \mathrm{NaOH}$; dissolved in water) or water (0 mM IAA; control) using a 25-gauge needle attached to a $15 \mathrm{ml}$ syringe. Treatments were injected at $0.05 \mathrm{ml} / \mathrm{g}$ of muscle to achieve a final concentration of $10,5,3.75,2.5,1.25,0.625$, or $0 \mu \mathrm{mol} \mathrm{IAA} / \mathrm{g}$ of muscle for the $200,100,75,50$, $25,12.5$, or 0 mM IAA solutions, respectively. To ensure even distribution throughout each steak, several sites spaced $\sim 1 \mathrm{~cm}$ apart were injected with $\sim 200 \mu \mathrm{l}$ of treatment solution. Injections were given through the top, bottom, and sides of the steaks. Then, an approximately $10 \mathrm{~g}$ sample was collected from each steak (subsequently referred to as $0 \mathrm{~h}$ sample), snap frozen in liquid nitrogen, and immediately stored at $-80^{\circ} \mathrm{C}$ for $\mathrm{pH}$ analysis. Color measurements were then collected before steaks were vacuum packaged and stored at $4{ }^{\circ} \mathrm{C}$. The pouches $(20 \times 30 \mathrm{~cm}$; LK Plastics, Los Angeles, CA, USA) used were $76-\mu \mathrm{m}$ thick, with an oxygen permeability of $0.6 \mathrm{~cm}^{3} / 100 \mathrm{~m}^{2} / 24 \mathrm{~h}$ at $0{ }^{\circ} \mathrm{C}$, and a water vapor transmission rate of $0.6 \mathrm{~g} / 100 \mathrm{~m}^{2} / 24 \mathrm{~h}$ at $38{ }^{\circ} \mathrm{C}$ and $100 \%$ relative humidity. Additional pH samples and color measurements were collected from each steak at 3, 6, 24 , and $48 \mathrm{~h}$ post-mortem in the same manner described above, in which vacuum packages were 
opened prior to $\mathrm{pH}$ sample collection and color measurements and resealed afterward. The study was conducted over a period of 5 days, with one animal harvested each day.

In a follow-up study, eight young steers (12-13 months old; $321.6 \pm 10.8 \mathrm{~kg}$ live weight) were harvested in the same manner as the previous study. The LTL muscle was excised within 30 min of exsanguination and fabricated into eight $2.5-\mathrm{cm}$ steaks. Steaks were randomly injected at $0.05 \mathrm{ml} / \mathrm{g}$ of muscle with either $100 \mathrm{mM}$ IAA solution (adjusted to $\mathrm{pH} 7.0$ with $1 \mathrm{M} \mathrm{NaOH}$; dissolved in water) to achieve a final concentration of $5 \mu \mathrm{mol} \mathrm{IAA} / \mathrm{g}$ of muscle or water (as control). One steak from each treatment was immediately used ( $0 \mathrm{~h}$ storage $)$ while the remaining steaks were vacuum packaged and stored at $4{ }^{\circ} \mathrm{C}$ for $24,168(7 \mathrm{~d})$, and $336 \mathrm{~h}(14 \mathrm{~d})$ (one steak per treatment for each storage period). At the end of each storage period, steaks were removed from their packages and color was evaluated. Then, each steak was cut into two portions. One portion was used for drip loss, cook loss, and texture profile analysis (TPA) determination, while the other portion was snap frozen in liquid nitrogen and stored at $-80{ }^{\circ} \mathrm{C}$ for further analysis. Samples were collected over 8 days, with one animal harvested each day.

In a third study, the LTL muscle of four out of the eight animals used in the previous study was collected from the right side of the carcass at $48 \mathrm{~h}$ postmortem. The muscle was fabricated into two 2.5-cm steaks. One steak was injected with $100 \mathrm{mM}$ IAA ( $\mathrm{pH}=7.0$; dissolved in water) to achieve a final concentration of $5 \mu \mathrm{mol} \mathrm{IAA} / \mathrm{g}$ of muscle while the other was injected with water (control) following the protocol as above. Steaks were vacuum packaged and stored at $4{ }^{\circ} \mathrm{C}$ for a period of $14 \mathrm{~d}$. Color and $\mathrm{pH}$ measurements were collected at 0 (right after injection), 24, 168, and $336 \mathrm{~h}$. 


\subsection{Muscle $p H$}

Frozen samples collected at $0,3,6,24$, and $48 \mathrm{~h}$ from the first experiment and $0,24,168$, and 336 $\mathrm{h}$ from the second experiment were prepared for $\mathrm{pH}$ measurement as described by Bendall (1973) with modifications. In brief, samples were powdered under liquid nitrogen and then homogenized at 1:8 (w/v) in ice-cold buffer containing $5 \mathrm{mM} \mathrm{IAA}$ and $150 \mathrm{mM} \mathrm{KCl}$ (adjusted to $\mathrm{pH} 7.0$ with 1 M NaOH) using a bead-beating homogenizer (TissueLyser LT, Qiagen, Hilden, Germany). Homogenates were then centrifuged at $17,000 \times g$ for $5 \mathrm{~min}$, equilibrated to $25^{\circ} \mathrm{C}$, and measured directly using an Orion Ross Ultra pH electrode coupled to an Orion Star A214 pH/ISE benchtop meter (Thermo Scientific, Pittsburgh, PA, USA).

\subsection{Color analysis}

Instrumental color measurements were performed using a Konica Minolta chromameter (CR400, Konica Minolta Sensing Inc., Osaka, Japan) with illuminant D65, $2^{\circ}$ observer angle, and 8 $\mathrm{mm}$ aperture diameter. Prior to color measurements, the instrument was calibrated with a white standard plate provided by the manufacturer. Steaks were removed from their packages, allowed to bloom for $20 \mathrm{~min}$ at room temperature, and at least four random measurements were collected over locations free of any noticeable color defects. Obtained values were averaged and expressed in terms of Commission Internationale de l'Éclairage (CIE) L* (lightness), a* (redness), and b* (yellowness).

\subsection{Cook loss and texture profile analysis}

Texture profile analysis was performed on both raw and cooked meat samples using a 75-mm diameter stainless steel plate connected to a TMS-Pro Texture Analyzer (Food Technology Co., Sterling, VA, USA) following the methods outlined by Dang et al. (2020a) with a minor modification. One slice from each steak was immediately used for raw TPA, while cooked TPA 
was evaluated on a different slice. Slices designated for cooked TPA were weighed and cooked on a clamshell grill to an internal temperature of $71{ }^{\circ} \mathrm{C}$. Temperature was monitored using a digital scanning thermometer with the probe placed in the geometric center of the steak. Samples were allowed to cool to room temperature, blotted dry, weighed again, and stored overnight at $4{ }^{\circ} \mathrm{C}$. Cook loss was calculated as a percentage loss from the initial weight of the sample. The next day, samples were brought to room temperature prior to TPA analysis. Two 2-cm thick cubes of raw and cooked samples were obtained using a knife. Each cube was placed under the compression plate with the muscle fibers oriented perpendicular to the plate. Cubes were then compressed to $30 \%$ of their original height. After the initial compression, the plate returned to its original zeroed position before the start of the second cycle. The plate was set to move at $100 \mathrm{~mm} / \mathrm{min}$. Kilogram of force per mm was recorded throughout the compression process. Calculations for hardness, cohesiveness, springiness, gumminess, and chewiness were based on equations described by Bourne (2002).

\subsection{Drip loss}

Drip loss was determined using the method described by Rasmussen \& Stouffer (1996). Drip loss was only evaluated on the $24 \mathrm{~h}$ samples from the second study. Briefly, two cores ( $\sim 10 \mathrm{~g}$ each) were collected from each steak with a 2.5 -cm-diameter coring device, weighed, and then placed individually in a drip loss tube. Tubes were stored for $48 \mathrm{~h}$ at $4{ }^{\circ} \mathrm{C}$. Following, samples were removed from the tube, blotted dry with paper towels to remove any surface moisture, and weighed again. Drip loss was calculated as a percentage loss from the original weight of the sample.

\subsection{Myoglobin abundance determination}

Myoglobin abundance was determined using western blot analysis as described previously by Dang, Buhler, Thornton, Legako, \& Matarneh (2020b). Muscle samples were homogenized in a 
solubilization buffer ( $8 \mathrm{M}$ urea, $2 \mathrm{M}$ thiourea, 3\% SDS [w/v], $75 \mathrm{mM}$ dithiothreitol, $50 \mathrm{mM}$ Tris$\mathrm{HCl}, \mathrm{pH}$ 6.8) at $100 \mathrm{mg}$ of muscle/ml of buffer (Warren, Krzesinski, \& Greaser, 2003) using a bead-beating homogenizer. Samples were then heated at $90{ }^{\circ} \mathrm{C}$ for $5 \mathrm{~min}$, centrifuged at $10,000 \times \mathrm{g}$ for $10 \mathrm{~min}$, and the supernatants were transferred to new tubes. Protein concentration was determined using the RC DC protein kit according to manufacturer's directions (BioRad Laboratories, Hercules, CA, USA). Muscle samples were then diluted to $3 \mathrm{mg}$ protein/ml using the same solubilization buffer supplemented with $0.05 \%$ bromophenol. Samples were subjected to $95{ }^{\circ} \mathrm{C}$ for 5 min prior to separation by SDS-PAGE. A $14 \%$ polyacrylamide resolving gel $(46.7 \%$ [vol $/ \mathrm{vol}$ ] 30\% acrylamide/ $0.8 \%$ bisacrylamide, $0.37 \mathrm{M}$ Tris, $\mathrm{pH} 8.8,0.1 \%$ [wt $/ \mathrm{vol}$ ] SDS, $0.13 \%$ [wt/vol] ammonium persulfate, and $0.07 \%$ [vol/vol] TEMED) was used for separation of proteins. The gels were ran using a $60 \mathrm{~V}$ current for $20 \mathrm{~min}$, followed by $120 \mathrm{~V}$ for $80 \mathrm{~min}$. Separated proteins were transferred to nitrocellulose membranes and reversibly stained with Ponceau $\mathrm{S}$ to determine total protein within each lane using a UVP ChemStudio Imaging System and software (Analytik Jena, Upland, CA, USA). Membranes were blocked with 3\% casein in PBS and $0.1 \%$ Tween-20 for $1 \mathrm{~h}$ at room temperature and immunoblotted for $16 \mathrm{~h}$ with a primary antibody specific for myoglobin (SC393020, Santa Cruz Biotechnology, Dallas, TX, USA). The membranes were then incubated with a fluorescent secondary antibody and imaged using the same imaging system and software. Band intensities were quantified and normalized to the intensity of total protein as measured by the Ponceau S image within each lane.

\subsection{Metabolite analysis}

Glycogen samples were prepared by adding $1 \mathrm{ml}$ of $1.25 \mathrm{M} \mathrm{HCl}$ to $\sim 0.1 \mathrm{~g}$ powdered muscle samples. The resulting mixture was then incubated for $2 \mathrm{~h}$ at $90{ }^{\circ} \mathrm{C}$, centrifuged at $17,000 \times g$ for 5 min at room temperature, and supernatants were neutralized with $1.25 \mathrm{M} \mathrm{KOH}$. Muscle lactate, 
glucose, and glucose-6-phosphate were measured on $\sim 0.1 \mathrm{~g}$ samples homogenized in $1 \mathrm{ml}$ of 0.5 M perchloric acid. Samples were incubated on ice for $20 \mathrm{~min}$, centrifuged at $17,000 \times \mathrm{g}$ for $5 \mathrm{~min}$, and supernatants were neutralized with $0.5 \mathrm{M} \mathrm{KOH}$ (Bergmeyer, 1984). Concentrations ( $\mu \mathrm{mol} / \mathrm{g}$ of muscle) of glycogen, lactate, glucose, and glucose-6-phosphate were measured spectrophotometrically at $340 \mathrm{~nm}$ with enzymatic methods modified for a 96-well plate (Hammelman et al., 2003). All measurements were performed in triplicate.

\subsection{Statistical analysis}

Color and $\mathrm{pH}$ data from the first experiment was analyzed using the mixed model of JMP (SAS Institute Inc., Cary, NC, USA) for repeated measures with steak as the experimental unit. The statistical model included the fixed effects of treatment, time, and their interaction and the random effect of steak. The slice function was used to determine treatment effect at individual time points and time effect within each treatment. For the second experiment, data were analyzed as a $2 \times 4$ factorial arrangement including treatment ( 0 or $5 \mu \mathrm{mol} \mathrm{IAA} / \mathrm{g}$ of muscle) and time $(0,24,168$, or $336 \mathrm{~h}$ ) using the mixed model of JMP. The statistical model included the fixed effects of treatment, time, and the 2-way interaction and the random effect of steak. If no significant interaction was found, only significant main effects were reported. Post hoc analysis for all experiments was performed using a Student's t-test and considered significant at $\mathrm{P} \leq 0.05$. All data are expressed as least-squares means $\pm \mathrm{SE}$.

\section{RESULTS AND DISCUSSION}

\subsection{First experiment}

During the post-mortem period, skeletal muscle $\mathrm{pH}$ drops due to the accumulation of $\mathrm{H}^{+}$generated from ATP hydrolysis by muscle ATPases (England, Scheffler, Kasten, Matarneh, \& Gerrard, 2013). The two ATP-generating reactions of glycolysis, phosphoglycerate kinase and pyruvate 
kinase, are downstream to that of GAPDH. Therefore, inhibiting GAPDH activity arrests glycolytic ATP production, and ultimately, $\mathrm{pH}$ decline. In our first experiment, different concentrations of IAA were injected into pre-rigor bovine LTL muscle samples to test whether IAA is capable of inhibiting glycolysis in "intact" steaks and to find the minimum IAA concentration for creating dark cutting-like beef. Because muscle $\mathrm{pH}$ continues to drop as postmortem time progresses, we chose to use muscle that was excised shortly after harvest to ensure that $\mathrm{pH}$ was still elevated.

\subsubsection{Effect of different concentrations of IAA on the pH of LTL muscle}

No differences were observed between treatments for $\mathrm{pH}$ at 0,3 , or $6 \mathrm{~h}$ post-mortem (Table 1 ). At 24 and $48 \mathrm{~h}$, however, the $\mathrm{pH}$ increased $(P<0.0001)$ with increasing the concentration of IAA from 0 to $1.25 \mu \mathrm{mol} / \mathrm{g}$ of muscle and plateaued at $2.5 \mu \mathrm{mol} / \mathrm{g}$ of muscle. In the 0 and $0.625 \mu \mathrm{mol}$ IAA/g of muscle treatments, muscle $\mathrm{pH}$ gradually declined $(P<0.0001)$ within the first $24 \mathrm{~h}$ postmortem. In contrast, the decline in $\mathrm{pH}$ plateaued $(P \leq 0.05)$ at $3 \mathrm{~h}$ in the $2.5,3.75$, and $5 \mu \mathrm{mol}$

IAA/g of muscle treatments, whereas no time effect for $\mathrm{pH}$ was detected in the $10 \mu \mathrm{mol} \mathrm{IAA} / \mathrm{g}$ of muscle. No additional reduction in $\mathrm{pH}$ was observed between 24 and $48 \mathrm{~h}$ in any treatment. These data indicate that IAA successfully inhibited $\mathrm{pH}$ decline in pre-rigor bovine LTL muscle samples. De Fremery (1966) and Bouton et al. (1971) reported similar pH results in animals injected with IAA or epinephrine prior to harvest. The inhibitory effect of IAA on $\mathrm{pH}$ decline seems to be concentration dependent, at least between 0 and $2.5 \mu \mathrm{mol} / \mathrm{g}$ of muscle. Curiously, a 0.2-0.3-unit decrease in $\mathrm{pH}$ of the LTL muscle was observed within the first $6 \mathrm{~h}$ in all treatments, suggesting that $\mathrm{H}^{+}$continued to accumulate in the muscle early post-mortem. This reduction in $\mathrm{pH}$ is likely due to the presence of glycolytic intermediates beyond GAPDH at the time of treatment injection, which were completely metabolized through anaerobic glycolysis to lactate and contributed to $\mathrm{pH}$ 
Table 1. Effect of different iodoacetic acid (IAA) concentrations on $\mathrm{pH}, \mathrm{L}^{*}$, $\mathrm{a}^{*}$, and $\mathrm{b}^{*}$ of the LTL muscle at $0,3,6,24$, and $48 \mathrm{~h}$ post-mortem. Data are least-squares means \pm SE. ${ }^{\text {a-d }}$ Means lacking a common superscript letter differ significantly within the same row. ${ }^{\mathrm{x}-\mathrm{z}}$ Means lacking a common superscript letter differ significantly within the same column for each variable.

\begin{tabular}{|c|c|c|c|c|c|c|c|c|c|}
\hline \multirow{2}{*}{ Item } & \multicolumn{7}{|c|}{ Treatment ( $\mu$ mol IAA/g of muscle) } & \multirow{2}{*}{$\mathrm{SE}$} & \multirow{2}{*}{ P-value } \\
\hline & 0 & 0.625 & 1.25 & 2.50 & 3.75 & 5 & 10 & & \\
\hline \multicolumn{10}{|l|}{$\mathrm{pH}$} \\
\hline $0 \mathrm{~h}$ & $6.54^{\mathrm{x}}$ & $6.57^{\mathrm{x}}$ & $6.56^{\mathrm{x}}$ & $6.54^{\mathrm{x}}$ & $6.67^{x}$ & $6.61^{\mathrm{x}}$ & 6.56 & 0.16 & 0.94 \\
\hline $3 \mathrm{~h}$ & $6.46^{\mathrm{x}}$ & $6.37^{\mathrm{xy}}$ & $6.46^{\mathrm{x}}$ & $6.39^{\mathrm{xy}}$ & $6.47^{\mathrm{xy}}$ & $6.38^{\mathrm{y}}$ & 6.36 & 0.18 & 0.93 \\
\hline $6 \mathrm{~h}$ & $6.21^{\mathrm{y}}$ & $6.25^{\mathrm{y}}$ & $6.25^{\mathrm{y}}$ & $6.36^{x y}$ & $6.35^{\mathrm{y}}$ & $6.47^{x y}$ & 6.27 & 0.16 & 0.36 \\
\hline $24 \mathrm{~h}$ & $5.53^{\mathrm{c}, \mathrm{z}}$ & $5.84^{\mathrm{b}, \mathrm{z}}$ & $6.07^{\mathrm{b}, \mathrm{yz}}$ & $6.36^{\mathrm{a}, \mathrm{xy}}$ & $6.39^{\mathrm{a}, \mathrm{y}}$ & $6.35^{\mathrm{a}, \mathrm{y}}$ & $6.33^{\mathrm{a}}$ & 0.22 & $<0.0001$ \\
\hline $48 \mathrm{~h}$ & $5.60^{\mathrm{d}, \mathrm{z}}$ & $5.82^{\mathrm{cd}, \mathrm{z}}$ & $5.98^{\mathrm{bc}, \mathrm{z}}$ & $6.20^{\mathrm{ab}, \mathrm{y}}$ & $6.34^{\mathrm{a}, \mathrm{y}}$ & $6.33^{\mathrm{a}, \mathrm{y}}$ & $6.37^{\mathrm{a}}$ & 0.20 & $<0.0001$ \\
\hline SE & 0.14 & 0.19 & 0.18 & 0.15 & 0.15 & 0.12 & 0.14 & - & - \\
\hline P-value & $<0.0001$ & $<0.0001$ & $<0.0001$ & 0.03 & 0.01 & 0.05 & 0.09 & - & - \\
\hline \multicolumn{10}{|l|}{$\mathrm{L}^{*}$} \\
\hline $0 \mathrm{~h}$ & $33.8^{\mathrm{y}}$ & $33.6^{\mathrm{yz}}$ & $33.1^{\mathrm{yz}}$ & $33.7^{x y}$ & $33.1^{\mathrm{x}}$ & $33.7^{x}$ & 33.3 & 1.57 & 0.99 \\
\hline $3 \mathrm{~h}$ & $32.3^{z}$ & $31.8^{z}$ & $31.9^{z}$ & $31.6^{z}$ & $30.8^{y}$ & $31.5^{z}$ & 32.7 & 1.77 & 0.78 \\
\hline $6 \mathrm{~h}$ & $31.9^{z}$ & $32.4^{z}$ & $32.2^{z}$ & $31.4^{\mathrm{z}}$ & $30.7^{y}$ & $32.0^{\mathrm{yz}}$ & 32.4 & 1.70 & 0.77 \\
\hline $24 \mathrm{~h}$ & $38.4^{\mathrm{a}, \mathrm{x}}$ & $34.3^{\mathrm{b}, \mathrm{y}}$ & $33.7^{\mathrm{bc}, \mathrm{xy}}$ & $32.6^{\mathrm{bc}, \mathrm{yz}}$ & $31.9^{c, x y}$ & $32.2^{\mathrm{c}, \mathrm{xyz}}$ & $32.6^{\mathrm{bc}}$ & 2.04 & $<0.0001$ \\
\hline $48 \mathrm{~h}$ & $39.6^{\mathrm{a}, \mathrm{x}}$ & $36.2^{\mathrm{b}, \mathrm{x}}$ & $35.0^{\mathrm{bc}, \mathrm{x}}$ & $34.3^{\mathrm{bc}, \mathrm{x}}$ & $32.7^{\mathrm{c}, \mathrm{x}}$ & $33.2^{\mathrm{c}, \mathrm{xy}}$ & $33.0^{\mathrm{c}}$ & 2.27 & $<0.0001$ \\
\hline $\mathrm{SE}$ & 1.36 & 1.40 & 1.92 & 1.55 & 1.73 & 1.32 & 1.41 & - & - \\
\hline P-value & $<0.0001$ & $<0.0001$ & 0.0002 & 0.0001 & 0.001 & 0.01 & 0.79 & - & - \\
\hline \multicolumn{10}{|l|}{$a^{*}$} \\
\hline $0 \mathrm{~h}$ & $14.9^{\mathrm{y}}$ & 14.7 & 14.8 & 14.7 & 13.8 & $15.4^{\mathrm{x}}$ & 15.0 & 1.49 & 0.79 \\
\hline $3 \mathrm{~h}$ & $14.8^{\mathrm{y}}$ & 15.5 & 14.9 & 14.0 & 13.4 & $14.5^{\mathrm{xy}}$ & 13.8 & 1.38 & 0.36 \\
\hline $6 \mathrm{~h}$ & $15.6^{\mathrm{a}, \mathrm{y}}$ & $14.3^{\mathrm{abc}}$ & $15.2^{\mathrm{ab}}$ & $14.1^{\mathrm{abc}}$ & $13.6^{\mathrm{bc}}$ & $13.1^{\mathrm{c}, \mathrm{y}}$ & $13.0^{\mathrm{c}}$ & 1.38 & 0.05 \\
\hline $24 \mathrm{~h}$ & $18.0^{\mathrm{a}, \mathrm{x}}$ & $15.6^{\mathrm{b}}$ & $15.0^{\mathrm{b}}$ & $14.9^{\mathrm{b}}$ & $14.3^{\mathrm{b}}$ & $13.8^{b, x y}$ & $14.6^{\mathrm{b}}$ & 1.51 & 0.001 \\
\hline $48 \mathrm{~h}$ & $17.6^{\mathrm{a}, \mathrm{x}}$ & $15.7^{\mathrm{bc}}$ & $16.7^{\mathrm{ab}}$ & $15.9^{\mathrm{abc}}$ & $14.6^{\mathrm{c}}$ & $15.2^{\mathrm{bc}, \mathrm{x}}$ & $14.3^{\mathrm{c}}$ & 1.78 & 0.01 \\
\hline $\mathrm{SE}$ & 1.38 & 1.59 & 1.47 & 1.06 & 0.99 & 1.03 & 0.98 & - & - \\
\hline P-value & $<0.0001$ & 0.24 & 0.07 & 0.07 & 0.42 & 0.01 & 0.07 & - & - \\
\hline \multicolumn{10}{|l|}{$b^{*}$} \\
\hline $0 \mathrm{~h}$ & $4.5^{z}$ & $4.7^{\mathrm{y}}$ & $4.6^{z}$ & $4.6^{z}$ & $4.3^{y}$ & 5.5 & 5.3 & 1.13 & 0.35 \\
\hline $3 \mathrm{~h}$ & $4.9^{\mathrm{yz}}$ & $5.6^{\mathrm{y}}$ & $5.6^{\mathrm{yz}}$ & $5.2^{\mathrm{yz}}$ & $5.1^{\mathrm{x}}$ & 5.8 & 5.5 & 0.64 & 0.71 \\
\hline $6 \mathrm{~h}$ & $5.8^{\mathrm{y}}$ & $5.6^{\mathrm{y}}$ & $5.9^{\mathrm{y}}$ & $5.6^{\mathrm{yz}}$ & $5.3^{\mathrm{x}}$ & 5.5 & 5.4 & 0.66 & 0.96 \\
\hline $24 \mathrm{~h}$ & $8.9^{\mathrm{a}, \mathrm{x}}$ & $6.8^{\mathrm{b}, \mathrm{x}}$ & $6.1^{\mathrm{bc}, \mathrm{xy}}$ & $5.9^{\mathrm{bc}, \mathrm{xy}}$ & $5.8^{\mathrm{bc}, \mathrm{x}}$ & $5.6^{\mathrm{c}}$ & $6.4^{\mathrm{bc}}$ & 0.86 & $<0.0001$ \\
\hline $48 \mathrm{~h}$ & $8.7^{\mathrm{a}, \mathrm{x}}$ & $6.9^{\mathrm{bc}, \mathrm{x}}$ & $7.0^{\mathrm{b}, \mathrm{x}}$ & $6.8^{\mathrm{bc}, \mathrm{x}}$ & $5.8^{\mathrm{c}, \mathrm{x}}$ & $6.2^{\mathrm{bc}}$ & $6.4^{\mathrm{bc}}$ & 1.31 & 0.0004 \\
\hline SE & 0.70 & 1.00 & 0.89 & 0.61 & 0.49 & 0.78 & 0.86 & - & - \\
\hline P-value & $<0.0001$ & 0.0002 & 0.0006 & 0.002 & 0.04 & 0.63 & 0.08 & - & - \\
\hline
\end{tabular}


decline. On the other hand, the additional drop in $\mathrm{pH}$ observed in the lower IAA treatments $(0.625$ and $1.25 \mu \mathrm{mol} / \mathrm{g}$ of muscle) seems to be a function of incomplete inhibition of GAPDH resulting from insufficient IAA.

\subsubsection{Effect of different concentrations of IAA on the color of LTL muscle}

To further test the effectiveness of the IAA treatment in generating dark cutting-like beef, color coordinates were also compared between treatments (Table 1). Although no treatment effect was observed at 0,3 , and $6 \mathrm{~h}$ post-mortem, $\mathrm{L}^{*}$ decreased $(P<0.0001)$ at 24 and $48 \mathrm{~h}$ as IAA concentration increased from 0 to $0.625 \mu \mathrm{mol} / \mathrm{g}$ of muscle and plateaued at $1.25 \mu \mathrm{mol} / \mathrm{g}$ of muscle. $\mathrm{L}^{*}$ values decreased $(P \leq 0.01)$ from 0 to $3 \mathrm{~h}$ in the $0,2.5,3.75$, and $5 \mu \mathrm{mol} \mathrm{IAA} / \mathrm{g}$ of muscle treatments, while no changes were observed in any treatment from 3 to $6 \mathrm{~h}$ post-mortem. Following this initial reduction, $\mathrm{L}^{*}$ values increased by $48 \mathrm{~h}$ in all treatments except the 5 and $10 \mu \mathrm{mol} \mathrm{IAA} / \mathrm{g}$ of muscle. A treatment effect $(P \leq 0.05)$ for a* was observed at 6,24 , and $48 \mathrm{~h}$. The control treatment had greater $\mathrm{a}^{*}$ value $(P=0.05)$ at $6 \mathrm{~h}$ post-mortem than those of $3.75,5$, and $10 \mu \mathrm{mol}$ IAA/g of muscle, while the $0.625,1.25$, and $2.5 \mu \mathrm{mol}$ IAA/g of muscle were intermediate. At 24 h post-mortem, greater a* $(P=0.001)$ was observed in the control steaks in comparison to all their IAA-treated counterparts. Compared to 0 and $1.25 \mu \mathrm{mol}$ IAA/g of muscle at $48 \mathrm{~h}$, steaks injected with 3.75 and $10 \mu \mathrm{mol} \mathrm{IAA} / \mathrm{g}$ of muscle had lower a* values $(P=0.01)$, while the remaining treatments were intermediate. No time effect was detected for $\mathrm{a}^{*}$ in the $0.625,1.25,2.5,3.75$, and $10 \mu \mathrm{mol} \mathrm{IAA} / \mathrm{g}$ of muscle treatments. On the other hand, an increase $(P<0.0001)$ from 6 to $24 \mathrm{~h}$ in $\mathrm{a}^{*}$ was observed in the control treatment. In steaks injected with $5 \mu \mathrm{mol}$ IAA/g of muscle, $\mathrm{a}^{*}$ decreased from 0 to $6 \mathrm{~h}$ and increased again $(P=0.01)$ at $24 \mathrm{~h}$ to a value comparable to the initial value. Greater $\mathrm{b}^{*}$ value $(P \leq 0.0004)$ was observed for the control steaks at 24 and $48 \mathrm{~h}$ compared to those injected with IAA, regardless of the concentration. Overall, $b^{*}$ increased $(P \leq 0.04)$ over 
the first $24 \mathrm{~h}$ post-mortem across all treatments except for the 5 and $10 \mu \mathrm{mol}$ IAA/g of muscle. There were no changes in $b^{*}$ from 24 to $48 \mathrm{~h}$. Taken together, our results show that IAA was able to decrease L*, $\mathrm{a}^{*}$, and $\mathrm{b}^{*}$ values of the LTL muscle in a concentration dependent manner. Similar to our results, previous studies have also shown decreased $\mathrm{L}^{*}, \mathrm{a}^{*}$, and $\mathrm{b}^{*}$ values in dark cutting beef (Abril et al., 2001; Zhang et al., 2018). The greatest difference in $\mathrm{L}^{*}$ (6.9 units) was obtained at $48 \mathrm{~h}$ between the control steaks $\left(\mathrm{L}^{*}=39.6\right)$ and the $3.75 \mu \mathrm{mol}$ IAA/g-injected steaks $\left(\mathrm{L}^{*}=\right.$ 32.7), a difference comparable to previously reported values between dark and normal-colored beef (Hughes, Clarke, Li, Purslow, \& Warner, 2019). Indeed, Norman, Berg, Heymann, \& Lorenzen (2003) indicated that a 5-unit difference in $\mathrm{L}^{*}$ value is enough for consumers to distinguish dark-colored meat and to influence their purchasing decisions. In addition to $\mathrm{L}^{*}$, reduction in redness also contributes to the dark appearance of dark cutters (Suman \& Joseph, 2013). In the current study, $>3$-unit difference in $\mathrm{a}^{*}$ was detected at $48 \mathrm{~h}$ between steaks injected with $10 \mu \mathrm{mol} I A A / g$ of muscle and controls.

Differences in color between treatments were not surprising, given the intimate relationship between $\mathrm{pH}$ and meat color; in general, the intensity of meat color decreases with increasing ultimate $\mathrm{pH}$ (Abril et al., 2001). Meat with high ultimate $\mathrm{pH}$ is further away from the average isoelectric point of muscle proteins $(\mathrm{pH}$ 5.1-5.2), which enhances its ability to retain water. Consequently, the size of the fiber is increased, allowing more light to penetrate deeply and be absorbed (Purslow et al., 2020). Additionally, less myoglobin is lost through purge and drip, resulting in a darker color. Although there is no single accepted $\mathrm{pH}$ cut-off point for dark cutting beef, it is generally agreed upon that beef with a $\mathrm{pH}$ value of $>6$ is regarded as dark cutter (Mahmood et al., 2017; Ponnampalam et al., 2017; Rosa et al., 2016). By this criterion, steaks 
injected with $2.5 \mu \mathrm{mol}$ IAA/g of muscle or more would be classified as dark cutter. Regardless, these data provide a wide range of $\mathrm{pH}$ and color values in which researchers can choose from.

\subsection{Second experiment}

Following the first study, a second experiment was conducted to test whether the observed effect can be maintained over an extended storage time, and to evaluate other dark cutting related characteristics that were not tested in the first experiment. In the second experiment, two treatments were tested, control and $5 \mu \mathrm{mol}$ IAA/g of muscle, at $0,24,168$, and $336 \mathrm{~h}$ post-mortem. Although no differences in $\mathrm{pH}$ and color measurements were observed in the first study between steaks injected with $2.5 \mu \mathrm{mol} \mathrm{IAA} / \mathrm{g}$ or more, we chose to use $5 \mu \mathrm{mol} \mathrm{IAA} / \mathrm{g}$ of muscle to ensure that IAA is not limiting. This is because IAA is light-sensitive and degrades over time, which reduces its inhibitory effect on GAPDH (Carne, 1994).

\subsection{1. $\mathrm{pH}$ and color}

Treatments differentially affected $(P<0.0001)$ the $\mathrm{pH}$ of the LTL muscle over time (treatment $\times$ time, Fig. 1). At $24 \mathrm{~h}$ post-mortem, the average $\mathrm{pH}$ of the treated steaks was about $0.6 \mathrm{pH}$ units higher $(P<0.0001)$ than that of the control steaks. This difference in $\mathrm{pH}$ between the two treatments was maintained over the $336 \mathrm{~h}$ post-mortem storage period. 


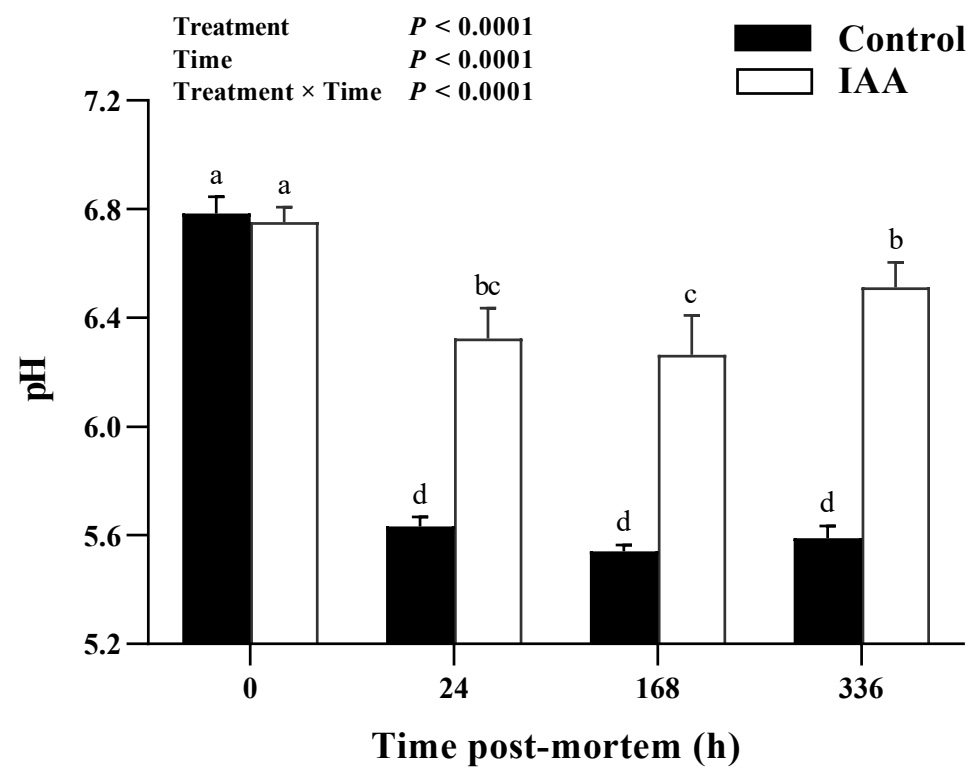

Fig. 1. $\mathrm{pH}$ of iodoacetic acid (IAA; $5 \mu \mathrm{mol} / \mathrm{g}$ of muscle)-injected and control steaks at $0,24,168$, and $336 \mathrm{~h}$ post-mortem. Data are least-squares means $\pm \mathrm{SE}$. ${ }^{\mathrm{a}-\mathrm{d}}$ Means lacking a common superscript letter differ significantly $(P \leq 0.05)$.

In addition to $\mathrm{pH}$, color measurements were also collected in this study (Fig. 2). Color differences between treatments are evident in representative images of steaks that were taken at $0,24,168$, and $336 \mathrm{~h}$ post-mortem (Fig. 2A). A significant treatment $\times$ time interaction $(P<0.0001)$ was detected for $\mathrm{L}^{*}, \mathrm{a}^{*}$, and $\mathrm{b}^{*}$ (Fig. 2B, C, and $\mathrm{D}$, respectively). Treated steaks had lower $(P \leq 0.0009)$ $\mathrm{L}^{*}, \mathrm{a}^{*}$, and $\mathrm{b}^{*}$ values than control steaks at $24 \mathrm{~h}$, and these differences were maintained for the duration of the study. Between 24 and $168 \mathrm{~h}$, a slight increase $(P<0.05)$ in $\mathrm{L}^{*}$, $\mathrm{a}^{*}$, and $\mathrm{b}^{*}$ values was observed in both treatments. 
$\mathbf{A}$
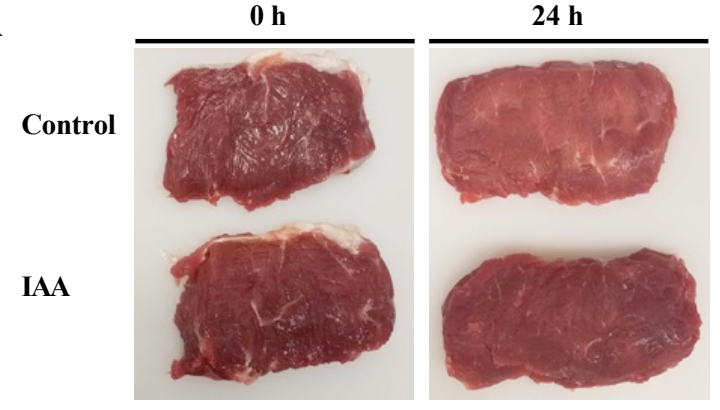

Control
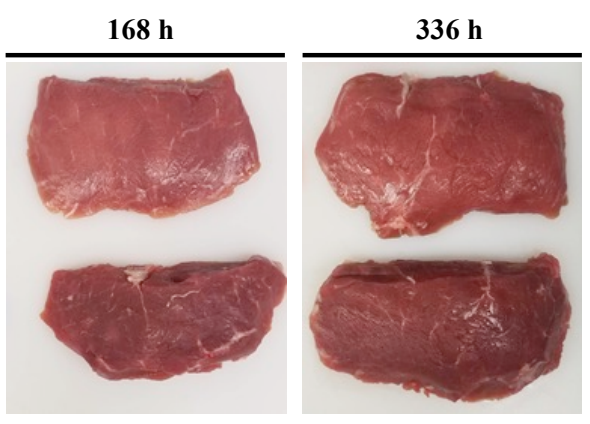

IAA

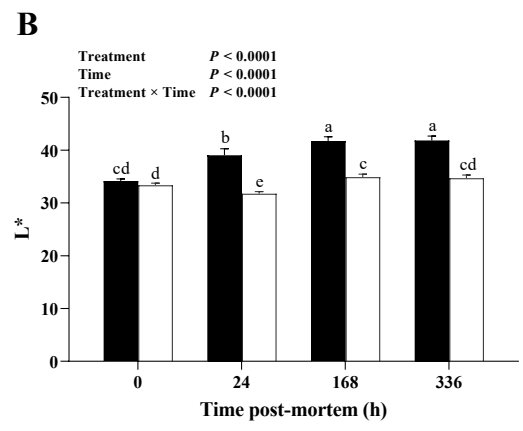

C

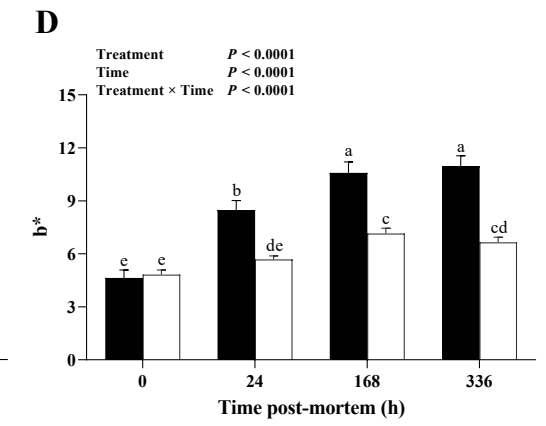

D

Fig. 2. Images (A), $\mathrm{L}^{*}(\mathrm{~B})$, $\mathrm{a}^{*}(\mathrm{C})$, and $\mathrm{b}^{*}(\mathrm{D})$ of iodoacetic acid (IAA; $5 \mu \mathrm{mol} / \mathrm{g}$ of muscle)injected and control steaks at $0,24,168$, and $336 \mathrm{~h}$ post-mortem. Data are least-squares means \pm SE. ${ }^{a-e}$ Means lacking a common superscript letter differ significantly $(P \leq 0.05)$.

This is probably due to a reduction in mitochondrial respiration at $168 \mathrm{~h}$. It has been shown that mitochondria lose functionality and structural integrity post-mortem (Tang et al., 2005), which impairs their capacity for respiration (England et al., 2018). This, in turn, allows for more oxygen to bind to myoglobin, thereby contributing to a larger percent oxymyoglobin and lighter meat (Ramanathan, Mancini, \& Konda, 2009). Alternatively, it is possible that more water expelled into spaces between muscle fibers by $168 \mathrm{~h}$, which increases light reflectance at the meat surface (Matarneh et al., 2017a). In agreement with these results, Wu et al. (2020) observed an increase in $\mathrm{L}^{*}, \mathrm{a}^{*}$, and $\mathrm{b}^{*}$ value of dark cutting beef over a 7 days storage period. However, Zhang et al. (2018) did not find any changes in color coordinates of vacuum packaged dark cutting steaks stored for 20 days. Collectively, these data confirm the results of the first experiment and indicate that the effect of IAA on $\mathrm{pH}$ and color is maintained over $336 \mathrm{~h}$ when injected at $5 \mu \mathrm{mol} / \mathrm{g}$ of muscle. 
Further, differences in color coordinates between the two treatments are more a function of increased L*, a* $b^{*}$ values in the control steaks (Fig 2), as IAA-treated steaks maintained their initial color values (at $0 \mathrm{~h}$ post-mortem) throughout the duration of the experiment.

\subsubsection{Glycolytic metabolites}

To better understand the impact of IAA on glycogenolysis and glycolysis, we compared glycogen and glycolytic metabolites between control and IAA-injected steaks. Glycogen is degraded during post-mortem metabolism by glycogen phosphorylase and debranching enzyme to yield glucose 6phosphate and glucose. Glucose 6-phosphate then enters glycolysis and is converted to lactate, whereas glucose is either converted to glucose 6-phosphate or accumulated in post-mortem muscle (Matarneh et al., 2017). A treatment $\times$ time interaction $(P \leq 0.01)$ was observed for glycogen, glucose, glucose 6-phosphate, and lactate (Fig. 3). Steaks injected with IAA had greater glycogen $(P \leq 0.02$, Fig. $3 \mathrm{~A})$ at 24,168 , and $336 \mathrm{~h}$ post-mortem and greater glucose $(P<0.0001$, Fig. 3B) at $336 \mathrm{~h}$ than their control counterparts. On the other hand, lower glucose 6-phosphate $(P \leq 0.01$, Fig. 3C) at 24 and $168 \mathrm{~h}$ and lower lactate $(P<0.0001$, Fig. 4D) at 24, 168, and $336 \mathrm{~h}$ was detected in the treated steaks. Data reported herein clearly demonstrate that injection of IAA inhibits postmortem glycolysis in pre-rigor bovine LTL muscle, as evidenced by lower glycogen degradation and lactate accumulation. Further, lower lactate values in the treated steaks strongly suggests that blunted pH decline in the same steaks (Fig. 1) was due to inhibition of glycolytic flux. Lactate values obtained from the IAA-injected steaks at $24 \mathrm{~h}$ or later are similar to those previously reported in dark cutters by McKeith et al. (2016). However, unlike naturally-occurring dark cutters, in the current study glycogen and glycolytic intermediates remained abundant over the entire storage period. This discrepancy is due to the different mechanism through which elevated 
ultimate $\mathrm{pH}$ is achieved in the naturally-occurring dark cutters (insufficient glycolysis due to substrate exhaustion) and our model (inhibition of glycolysis by IAA).
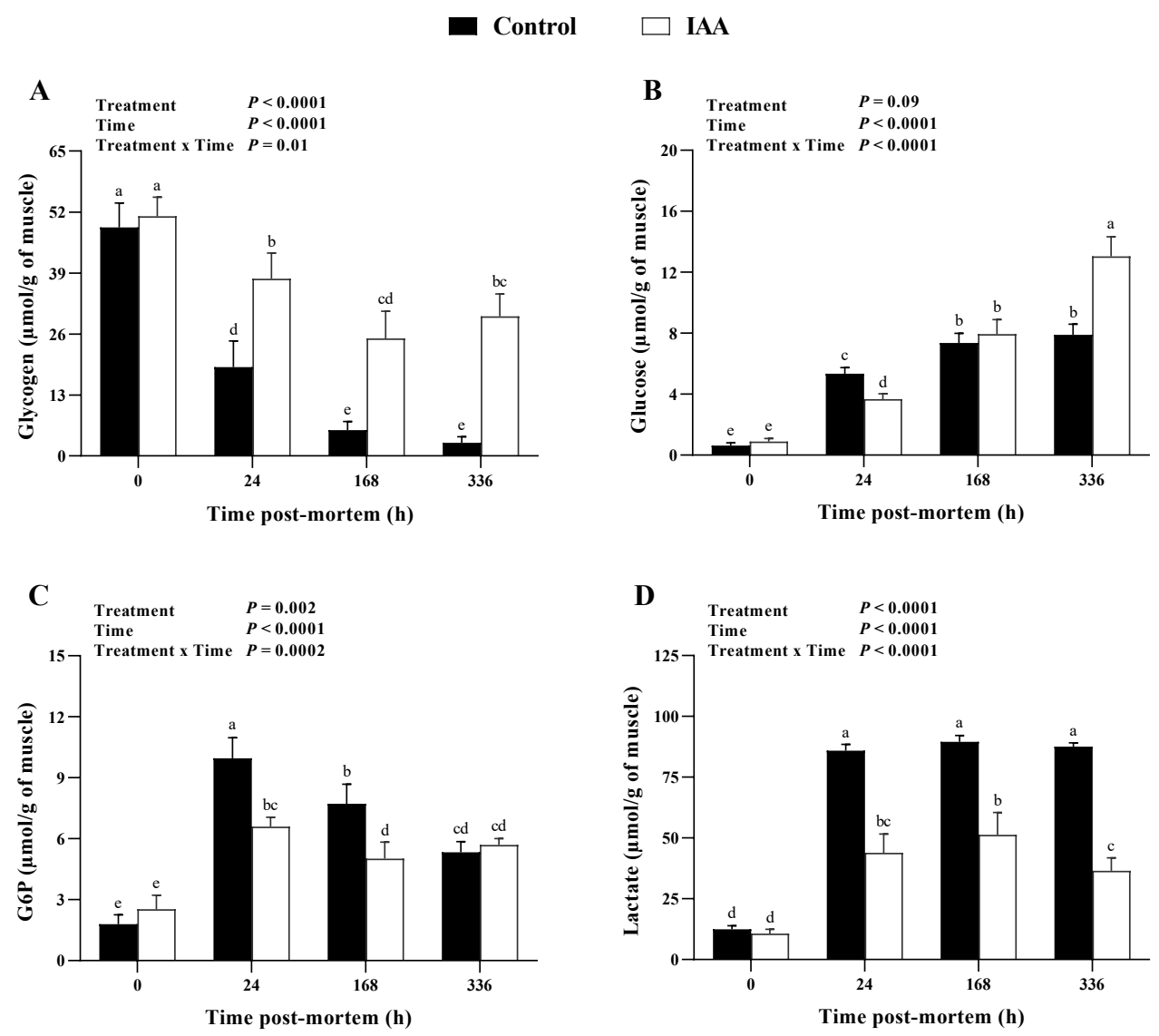

Fig. 3. Glycogen ( $\mu \mathrm{mol} / \mathrm{g}$ of muscle; A), glucose ( $\mu \mathrm{mol} / \mathrm{g}$ of muscle; B), glucose-6-phosphate (G6P; $\mu \mathrm{mol} / \mathrm{g}$ of muscle; $\mathrm{C}$ ), and lactate ( $\mu \mathrm{mol} / \mathrm{g}$ of muscle; D) of iodoacetic acid (IAA; $5 \mu \mathrm{mol} / \mathrm{g}$ of muscle)-injected and control steaks at $0,24,168$, and $336 \mathrm{~h}$ post-mortem. Data are least-squares means \pm SE. ${ }^{a-e}$ Means lacking a common superscript letter differ significantly $(P \leq 0.05)$.

\subsubsection{Water holding capacity}

Increased WHC is one of the major characteristics of dark cutting meat (den Hertog-Meischke et al., 1997). To evaluate WHC of control and IAA-injected steaks, drip and cook loss (\%) were tested in this study (Fig. 4). Drip loss (\%), measured on the $24 \mathrm{~h}$ samples, was decreased $(P<$ 0.0001) in the treated steaks than that of control steaks (Fig. 4A). Similarly, steaks injected with IAA had lower cook loss $(\%)(P \leq 0.02$, Fig. 4B) at 24,168 , and 336 h compared to controls. Drip 
and cook loss (\%) values obtained from steaks injected with IAA are comparable to those previously reported for epinephrine injected muttons (Bouton, et al., 1971) and dark cutters (Holdstock et al., 2014; Ijaz et al., 2020).

A

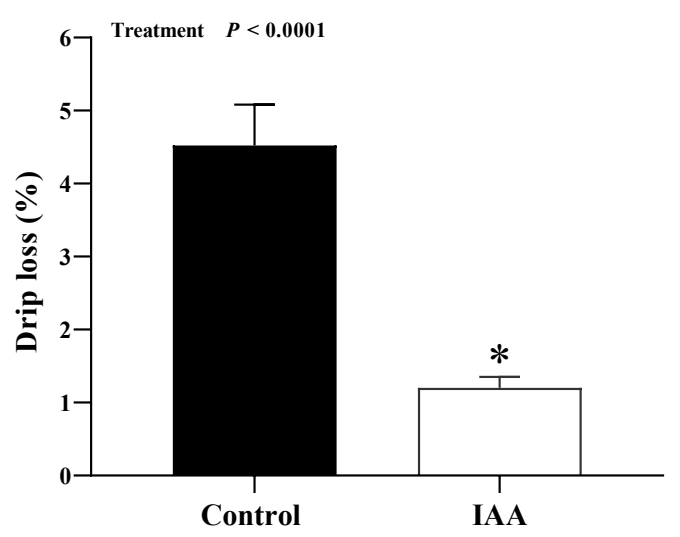

B

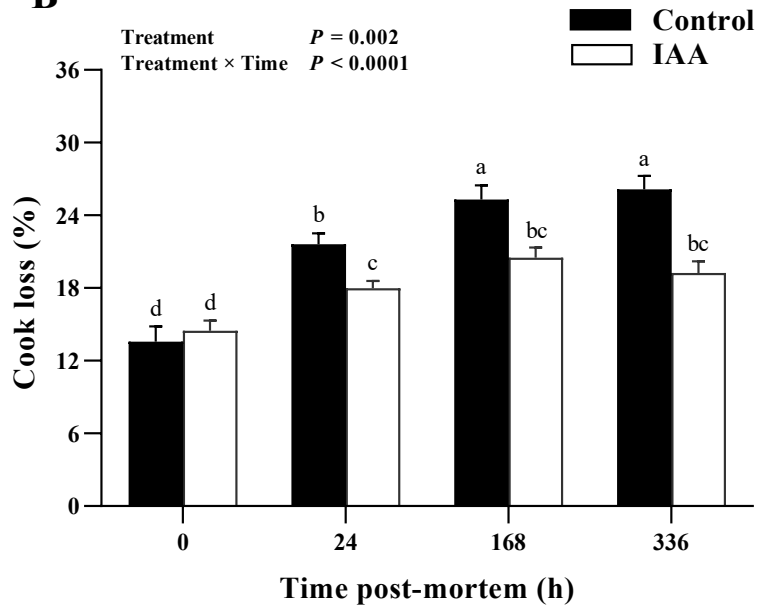

Fig. 4. Drip loss (\%; A) at $24 \mathrm{~h}$ post-mortem and cook loss $(\%$; B) at $0,24,168$, and 336 h postmortem of iodoacetic acid (IAA; $5 \mu \mathrm{mol} / \mathrm{g}$ of muscle)-injected and control steaks. Data are leastsquares means $\pm \mathrm{SE}$. *Indicates significant difference $(P \leq 0.05)$. ${ }^{\text {a-d }}$ Means lacking a common superscript letter differ significantly $(P \leq 0.05)$.

In addition to drip and cook loss (\%), WHC was indirectly evaluated through measuring myoglobin content on the $24 \mathrm{~h}$ samples (Fig. 5). WHC has a direct effect on myoglobin content of meat; as a water-soluble protein, myoglobin is subjected to loss during storage through purge and drip. Thus, increased WHC of meat limits the post-mortem loss of myoglobin, thereby increasing its content in the meat. As expected, myoglobin content was greater $(P=0.01)$ in the IAA-treated steaks than their control counterparts, which indicates enhanced WHC (Hunt \& Hedrick, 1977; Mahmood et al., 2017). Further, increased myoglobin levels in the treated steaks may have partially contributed to their darker color (Fig. 2). Enhanced WHC in the IAA-injected steaks is most likely due to their elevated $\mathrm{pH}$ values (Fig. 1). At high $\mathrm{pH}$, there is a net negative charge on most muscle proteins, which provides more charged groups available for water binding. Additionally, as net charge is 
increased, electrostatic repulsion between myofibrils increases, resulting in more interfilament space for water to be trapped.

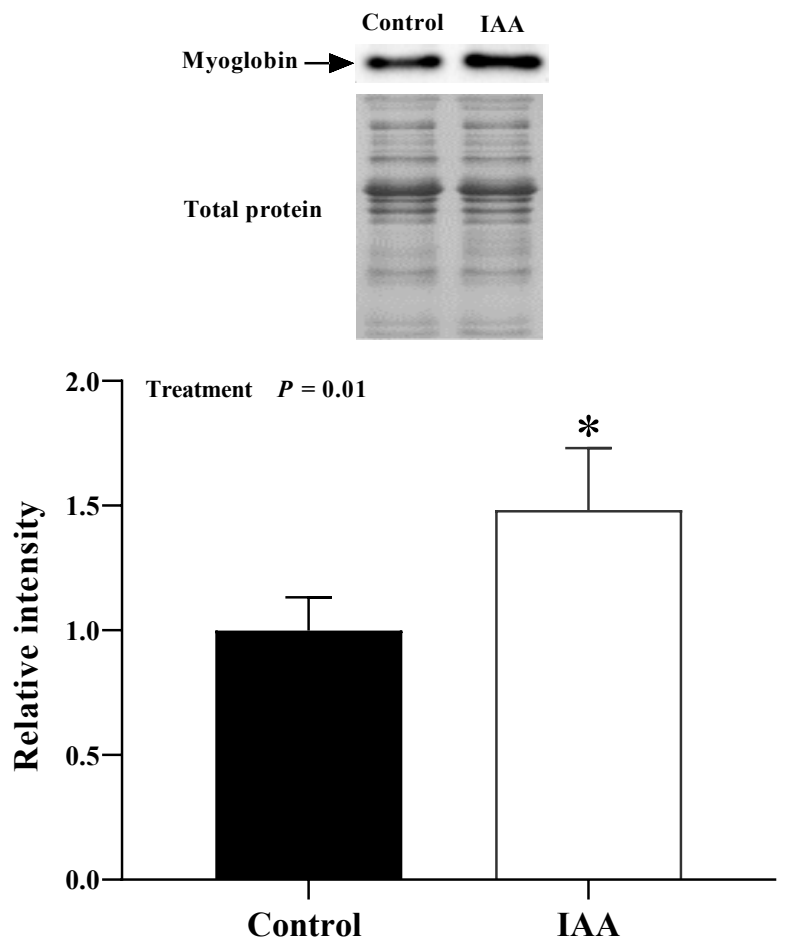

Fig. 5. Representative western blot (top) and relative band intensity (bottom) of myoglobin of iodoacetic acid (IAA; $5 \mu \mathrm{mol} / \mathrm{g}$ of muscle)-injected and control steaks at $24 \mathrm{~h}$ post-mortem. Data are least-squares means $\pm \mathrm{SE}$. *Indicates significant difference $(P \leq 0.05)$.

\subsubsection{Texture profile analysis}

In addition to its dark color, raw dark cutting meat also has a firm, rigid texture (Ponnampalam et al., 2017). Firmness associated with raw dark cutting meat is mainly due to its increased WHC, which causes the muscle fibers to become turgid (Swatland, 1995). However, instrumental analysis of cooked meat often finds that dark cutters are more tender than normal beef (Franco et al., 2015; Apple, Sawyer, Meullenet, Yancey, \& Wharton, 2011). Therefore, in order to better understand the impact of IAA treatment on meat texture, TPA was evaluated on both raw and cooked samples (Fig. 6 and 7, respectively). Springiness of raw samples was the only TPA parameter affected by 
the interaction of treatment $\times$ time, and therefore, only significant main effects for all other TPA parameters are presented in Fig. 6 and 7.

A
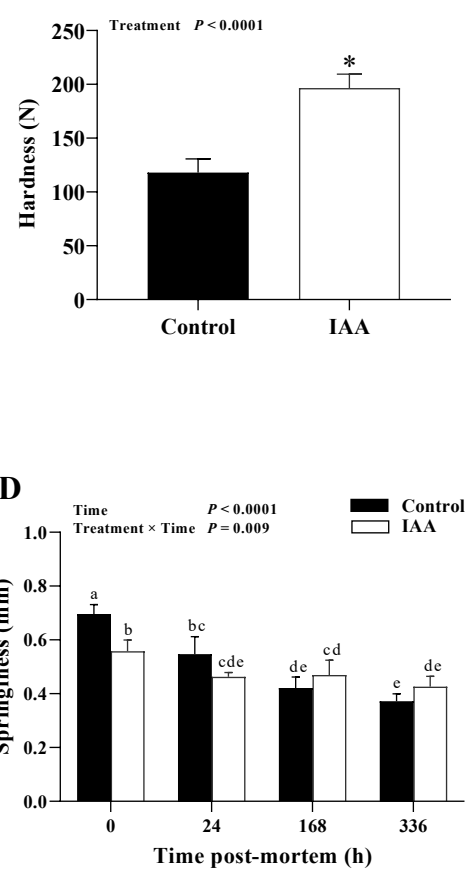

B

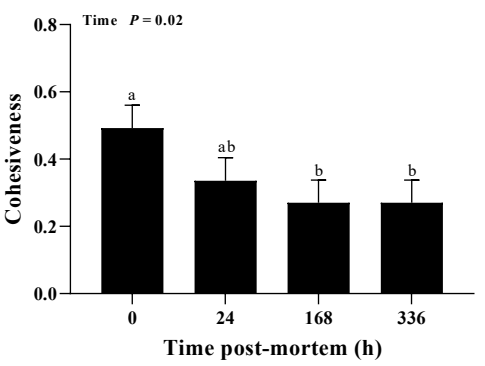

$\mathbf{E}$

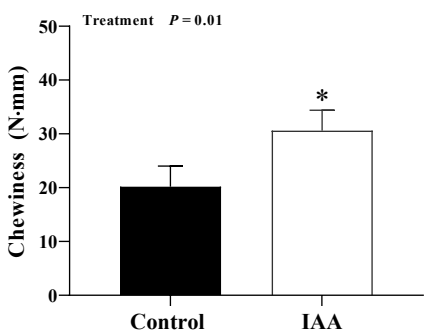

C

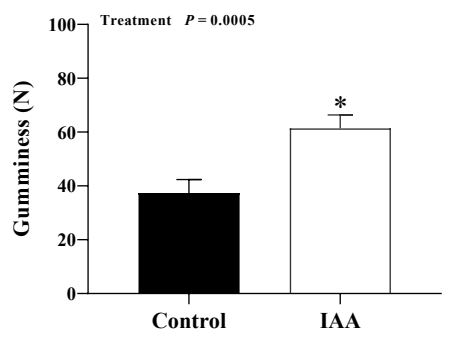

F

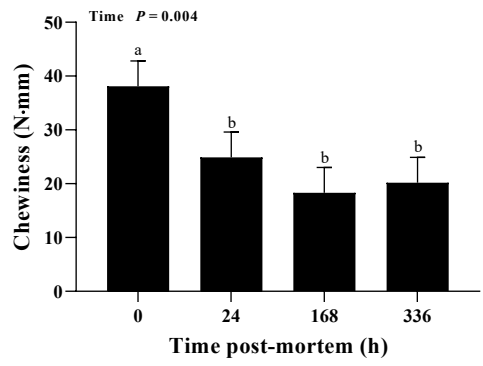

Fig. 6. Effect of treatment on raw LTL muscle hardness (N; A); effect of time on raw LTL muscle cohesiveness (B); effect of treatment on raw LTL muscle gumminess (N; C); springiness (mm; D) of iodoacetic acid (IAA; $5 \mu \mathrm{mol} / \mathrm{g}$ of muscle)-injected and control steaks at 0, 24, 168, and $336 \mathrm{~h}$ post-mortem; effect of treatment on raw LTL muscle chewiness (N.mm; E); effect of time on raw LTL muscle chewiness (N.mm; F). Data are least-squares means \pm SE. * Indicates significant difference $(P \leq 0.05)$. ${ }^{\mathrm{a}-\mathrm{e}}$ Means lacking a common superscript letter differ significantly $(P \leq 0.05)$.

A significant treatment effect $(P \leq 0.01)$ was observed for raw samples hardness, gumminess, and chewiness (Fig. 6A, C, and E, respectively), in which they were all greater in steaks injected with IAA. On the other hand, a time effect was found for raw samples cohesiveness and chewiness (Fig. 6B and F, respectively). Lower $(P=0.02)$ cohesiveness was detected at 168 and $336 \mathrm{~h}$ than that at $0 \mathrm{~h}$, while $24 \mathrm{~h}$ was intermediate. Similarly, chewiness value was greatest $(P=$ $0.004)$ at $0 \mathrm{~h}$ post-mortem in comparison to the other time points. The effect of treatment on raw springiness varied over time (treatment $\times$ time, $P=0.009$, Fig. $6 \mathrm{D}$ ). Steaks injected with IAA 
had lower springiness at $0 \mathrm{~h}$ than that of control, however, no differences between treatments were observed at 24, 168, and $336 \mathrm{~h}$. Hardness, gumminess, springiness, and chewiness of the cooked samples were all significantly affected by treatment (Fig. 7A, C, E, and F, respectively).

A

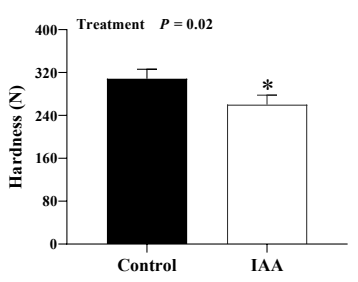

B

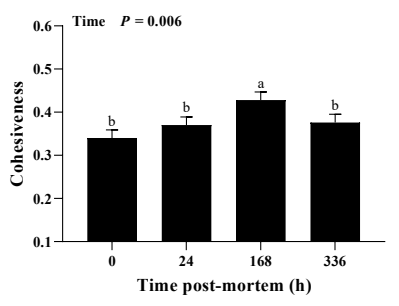

C

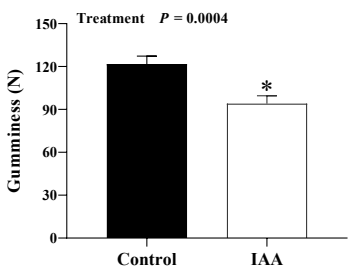

D

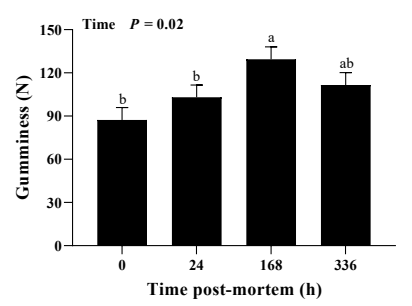

$\mathbf{E}$

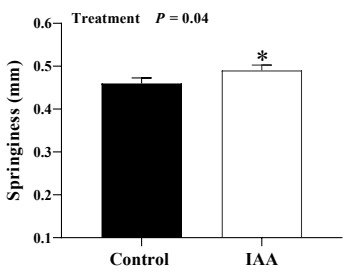

$\mathbf{F}$

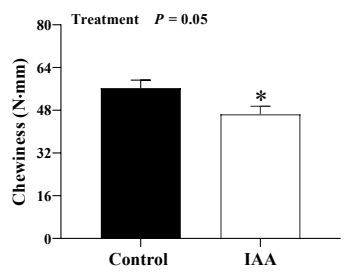

G

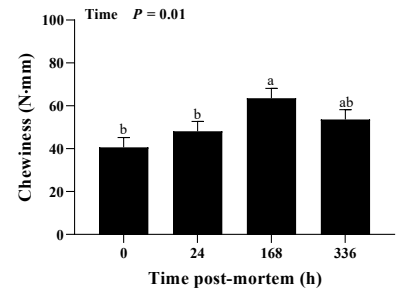

Fig. 7. Effect of treatment on cooked LTL muscle hardness (N; A); effect of time on cooked LTL muscle cohesiveness (B); effect of treatment on cooked LTL muscle gumminess (N; C); effect of time on cooked LTL muscle gumminess (N; D); effect of treatment on cooked LTL muscle springiness (mm; E); effect of treatment on cooked LTL muscle chewiness (N.mm; F); effect of time on cooked LTL muscle chewiness (N.mm; G). Data are least-squares means \pm SE. *Indicates significant difference $(P \leq 0.05)$. ${ }^{\mathrm{a}, \mathrm{b}}$ Means lacking a common superscript letter differ significantly $(P \leq 0.05)$.

Compared to control, steaks injected with IAA had lower $(P \leq 0.05)$ hardness, gumminess, and chewiness and greater springiness. A significant time effect was observed for cooked steaks cohesiveness, gumminess, and chewiness (Fig. 7B, D, and G, respectively). Cohesiveness value measured at $168 \mathrm{~h}$ was greater $(P=0.006)$ than those collected at $0,24,336 \mathrm{~h}$. Greater $(P \leq 0.02)$ gumminess and chewiness were observed at $168 \mathrm{~h}$ than 0 and $24 \mathrm{~h}$, while $336 \mathrm{~h}$ was intermediate. Our raw TPA data indicate that samples injected with IAA had a firmer texture than their control counterparts, as evidenced by their greater hardness, gumminess, and chewiness values. This increase in firmness is likely due to greater WHC in the IAA-treated 
samples (Ponnampalam et al., 2017). The opposite effect of IAA was observed in the cooked steaks, where hardness, gumminess, and chewiness were lower in the treated steaks. This effect is consistent with other studies that performed TPA on dark cutting steaks (Franco et al., 2015; Apple et al., 2011). The enhancement in meat texture of the IAA-injected steaks is likely due to enhanced proteolysis as high $\mathrm{pH}$ provides a more favorable environment for calpain-1 functionality, thereby enhancing proteolysis (Beltrán et al., 1997).

\subsection{Third experiment}

While the characteristics of the treated steaks in experiment 1 and 2 were consistent with dark cutters, a final experiment was performed to ensure that observed effects were due to inhibition of glycolysis and not due to "other" effects of IAA. In this experiment, IAA ( $5 \mu \mathrm{mol} / \mathrm{g}$ of muscle) was injected into steaks collected $48 \mathrm{~h}$ postmortem. We chose to use post-rigor steaks for this experiment to ensure that muscle ultimate $\mathrm{pH}$ was achieved (Fig. 1). No treatment effect on $\mathrm{pH}$ or color was observed (Fig. 8), which indicates that IAA does not influence the color or $\mathrm{pH}$ of the meat when injected into post-rigor steaks. This provides further evidence that the blunted $\mathrm{pH}$ decline of treated steaks from the previous experiments was most likely due to the inhibition of glycolysis and not any other effect of IAA. 
A

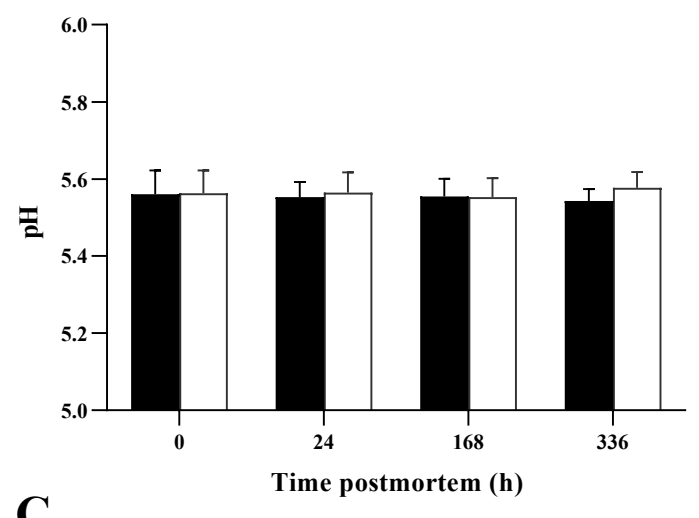

C

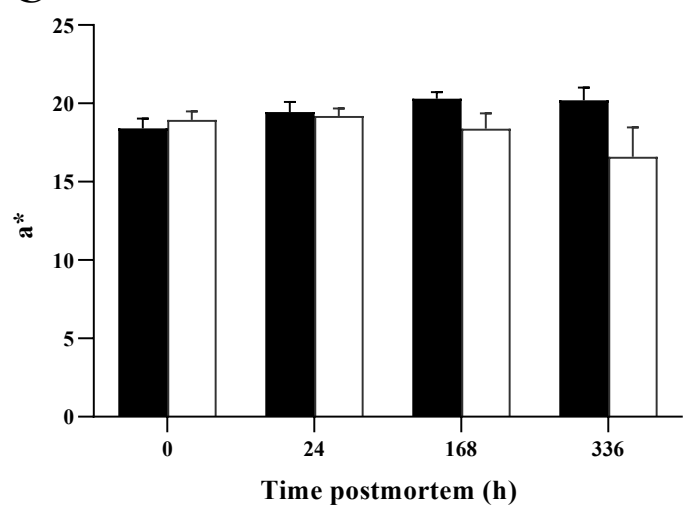

B
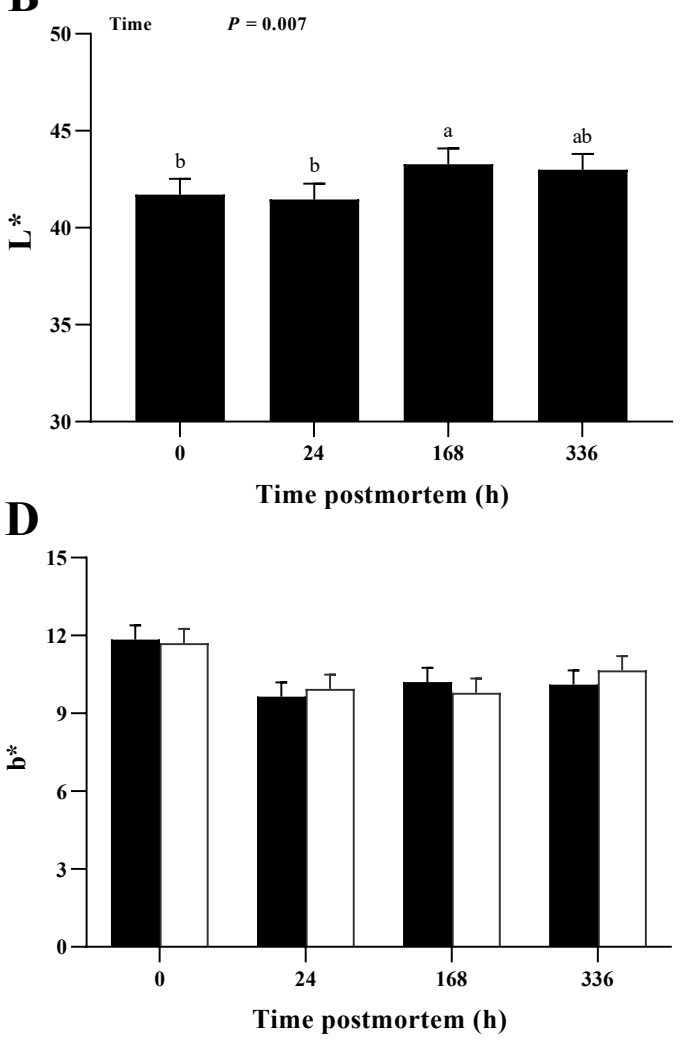

Fig. 8. $\mathrm{pH}$ of iodoacetic acid (IAA; $5 \mu \mathrm{mol} / \mathrm{g}$ of muscle)-injected and control steaks treated at 48 $\mathrm{h}$ post-mortem at $0,24,168$, and $336 \mathrm{~h}$ post-injection (A); Effect of time on $\mathrm{L}^{*}$ of steaks treated at $48 \mathrm{~h}(\mathrm{~B})$; $\mathrm{a}^{*}(\mathrm{C})$ and $\mathrm{b}^{*}(\mathrm{D})$ of steaks treated at $48 \mathrm{~h}$ post-mortem. Data are least-squares means \pm SE. ${ }^{a-b}$ Means lacking a common superscript letter differ significantly $(P \leq 0.05)$.

\section{CONCLUSIONS}

The results of this research demonstrate that injection of IAA into pre-rigor bovine LTL muscle generates beef with dark cutting-like characteristics. Similar to dark cutting beef, injection of IAA limits muscle's ability to perform glycolysis, resulting in meat with elevated ultimate $\mathrm{pH}$ and dark color. Based on the results of the first experiment, testing different concentrations of IAA indicated that $2.5 \mu \mathrm{mol} \mathrm{IAA} / \mathrm{g}$ of muscle or more is enough to generate dark cutting-like beef. Moreover, the second experiment demonstrated that injection of IAA at $5 \mu \mathrm{mol} / \mathrm{g}$ of muscle 
maintained dark cutting-like characteristics, including increased firmness and WHC, for a $336 \mathrm{~h}$ storage period. Therefore, this in situ model could be useful in facilitating dark cutting related research when it is challenging to obtain naturally-occurring dark cutters. While a step forward, one of the limitations of this model is that it cannot be used for sensory evaluation studies, as IAA is a toxic compound. 


\section{REFERENCES}

Abril, M., Campo, M. M., Önenç, A., Sañudo, C., Albertí, P., \& Negueruela, A. I. (2001). Beef colour evolution as a function of ultimate $\mathrm{pH}$. Meat Science, 58(1), 69-78.

Adeyemi, K. D., \& Sazili, A. Q. (2014). Efficacy of carcass electrical stimulation in meat quality enhancement: A review. Asian-Australasian journal of animal sciences, 27(3), 447.

Apple, J. K., Sawyer, J. T., Meullenet, J. F., Yancey, J. W. S., \& Wharton, M. D. (2011). Lactic acid enhancement can improve the fresh and cooked color of dark-cutting beef. Journal of animal science, 89(12), 4207-4220.

Ball, S. P., \& Johnson, K. J. (1993). The genetics of malignant hyperthermia. Journal of medical genetics, 30(2), 89-93.

Barbut, S., Sosnicki, A. A., Lonergan, S. M., Knapp, T., Ciobanu, D. C., Gatcliffe, L. J., ... Wilson, E. W. (2008). Progress in reducing the pale, soft and exudative (PSE) problem in pork and poultry meat. Meat Science, 79(1), 46-63.

Beltrán, J. A., Jaime, I., Santolaria, P., Sañudo, C., Albertí, P., \& Roncalés, P. (1997). Effect of stress-induced high post-mortem $\mathrm{pH}$ on protease activity and tenderness of beef. Meat Science, 45(2), 201-207.

Bendall, J. (1973). Postmortem Changes in Muscle. In The structure and function of muscle (pp. 234-309). New York: Academic Press.

Bergmeyer, H. U. (1984). Methods of enzymatic analysis, Vol. 6 (3rd ed.). Weinheim: Verlag Chemie.

Bogdanis, G. C., Nevill, M. E., Boobis, L. H., \& Lakomy, H. K. A. (1996). Contribution of phosphocreatine and aerobic metabolism to energy supply during repeated sprint exercise. Journal of Applied Physiology, 80(3), 876-884.

Bourne, M. (2002). Food texture and viscosity: concept and measurement. London: Academic Press.

Bouton, P. E., Harris, P. V., \& Shorthose, W. R. (1971). Effect of Ultimate pH upon the WaterHolding Capacity and Tenderness of Mutton. Journal of Food Science, 36(3), 435-439.

Boykin, C. A., Eastwood, L. C., Harris, M. K., Hale, D. S., Kerth, C. R., Griffin, D. B., ... Savell, J. W. (2017). National beef quality audit-2016: In-plant survey of carcass characteristics related to quality, quantity, and value of fed steers and heifers. Journal of Animal Science, 95(7), 2993-3002.

Carne, A. F. (1994). Chemical modification of proteins. In N.J Clifton (Ed.). Methods in molecular biology (pp. 311-320). Humana Press.

Çelen, M. F., Sögüt, B., Zorba, Ö., Demirulus, H., \& Tekeli, A. (2016). Comparison of normal 
and PSE turkey breast meat for chemical composition, $\mathrm{pH}$, color, myoglobin, and drip loss. Revista Brasileira de Zootecnia, 45(8), 441-444

Dang, D.S., Buhler, J. F., Davis, H. T., Thornton, K. J., Scheffler, T. L., \& Matarneh, S. K. (2020a). Inhibition of mitochondrial calcium uniporter enhances postmortem proteolysis and tenderness in beef cattle. Meat Science, 162. 108039.

Dang, David S., Buhler, J. F., Thornton, K. J., Legako, J. F., \& Matarneh, S. K. (2020b). Myosin heavy chain isoform and metabolic profile differ in beef steaks varying in tenderness. Meat Science, $170,108266$.

De Fremery, D. (1966). Relationship between Chemical Properties and Tenderness of Poultry Muscle. Journal of Agricultural and Food Chemistry, 14(3), 214-217.

den Hertog-Meischke, M. J. A., van Laack, R. J. L. M., \& Smulders, F. J. M. (1997). The waterholding capacity of fresh meat. Veterinary Quarterly, Vol. 19, pp. 175-181.

England, E. M., Matarneh, S. K., Mitacek, R. M., Abraham, A., Ramanathan, R., Wicks, J. C., ... Gerrard, D. E. (2018). Presence of oxygen and mitochondria in skeletal muscle early postmortem. Meat Science, 139, 97-106.

England, E. M., Matarneh, S. K., Oliver, E. M., Apaoblaza, A., Scheffler, T. L., Shi, H., \& Gerrard, D. E. (2016). Excess glycogen does not resolve high ultimate $\mathrm{pH}$ of oxidative muscle. Meat Science, 114, 95-102.

England, E. M., Matarneh, S. K., Scheffler, T. L., \& Gerrard, D. E. (2017). Perimortal Muscle Metabolism and its Effects on Meat Quality. In New Aspects of Meat Quality (pp. 63-89). Elsevier.

England, E. M., Matarneh, S. K., Scheffler, T. L., Wachet, C., \& Gerrard, D. E. (2015). Altered AMP deaminase activity may extend postmortem glycolysis. Meat Science, 102, 8-14.

England, E. M., Matarneh, S. K., Scheffler, T. L., Wachet, C., \& Gerrard, D. E. (2014). PH inactivation of phosphofructokinase arrests postmortem glycolysis. Meat Science, 98(4), $850-857$.

England, E. M., Scheffler, T. L., Kasten, S. C., Matarneh, S. K., \& Gerrard, D. E. (2013). Exploring the unknowns involved in the transformation of muscle to meat. Meat Science, 95(4), 837843.

Foxall, D. L., Brindle, K. M., Campbell, I. D., \& Simpson, R. J. (1984). The inhibition of erythrocyte glyceraldehyde-3-phosphate dehydrogenase in situ PMR studies. $B B A$ Molecular Cell Research, 804(2), 209-215.

Franco, D., Mato, A., Salgado, F. J., López-Pedrouso, M., Carrera, M., Bravo, S., ... Zapata, C. (2015). Tackling proteome changes in the longissimus thoracis bovine muscle in response to pre-slaughter stress. Journal of Proteomics, 122, 73-85. 
Hall, J. L., Latschar, C. E., \& Mackintosh, D. L. (1944). Characteristics of dark-cutting beef. Survey and preliminary investigation. Agric. Exp. Sta. Tech. Bull., 58(Part 4).

Hamm, R. (1977). Postmortem breakdown of ATP and glycogen in ground muscle: A review. Meat Science, 1(1), 15-39.

Hammelman, J. E., Bowker, B. C., Grant, A. L., Forrest, J. C., Schinckel, A. P., \& Gerrard, D. E. (2003). Early postmortem electrical stimulation simulates PSE pork development. Meat Science, 63(1), 69-77.

Hamoen, J. R., Vollebregt, H. M., \& Van Der Sman, R. G. M. (2013). Prediction of the time evolution of pH in meat. Food chemistry, 141(3), 2363-2372.

Hannula, T., \& Puolanne, E. (2004). The effect of cooling rate on beef tenderness: The significance of $\mathrm{pH}$ at 7 C. Meat Science, 67(3), 403-408.

Henckel, P., Karlsson, A., Jensen, M. T., Oksbjerg, N., \& Petersen, J. S. (2002). Metabolic conditions in Porcine longissimus muscle immediately pre-slaughter and its influence on peri- and post mortem energy metabolism. Meat Science, 62(2), 145-155.

Holdstock, J., Aalhus, J. L., Uttaro, B. A., López-Campos, Ó., Larsen, I. L., \& Bruce, H. L. (2014). The impact of ultimate $\mathrm{pH}$ on muscle characteristics and sensory attributes of the longissimus thoracis within the dark cutting (Canada B4) beef carcass grade. Meat Science, 98(4), 842-849.

Huda, N. (2011). Pale soft exudative (PSE) and dark firm dry (DFD) meats: Causes and measures to reduce these incidences-A mini review. In Article in International Food Research Journal, 18(1).

Hudson, N. J. (2012). Mitochondrial treason: a driver of $\mathrm{pH}$ decline rate in post-mortem muscle?. Animal Production Science, 52(12), 1107-1110.

Hughes, J., Clarke, F., Li, Y., Purslow, P., \& Warner, R. (2019). Differences in light scattering between pale and dark beef longissimus thoracis muscles are primarily caused by differences in the myofilament lattice, myofibril and muscle fibre transverse spacings. Meat Science, 149, 96-106.

Hughes, J. M., Oiseth, S. K., Purslow, P. P., \& Warner, R. D. (2014). A structural approach to understanding the interactions between colour, water-holding capacity and tenderness. Meat Science, 98(3), 520-532.

Hunt, M. C., \& Hedrick, H. B. (1977). Chemical, physical and sensory characteristics of bovine muscle from four quality groups. Journal of Food Science, 42(3), 716-720.

Ijaz, M., Li, X., Zhang, D., Hussain, Z., Ren, C., Bai, Y., \& Zheng, X. (2020). Association between meat color of DFD beef and other quality attributes. Meat Science, 161. 107954.

Immonen, K., Ruusunen, M., Hissa, K., \& Puolanne, E. (2000). Bovine muscle glycogen 
concentration in relation to finishing diet, slaughter and ultimate $\mathrm{pH}$. Meat Science, 55(1), 25-31.

Kemp, C. M., Sensky, P. L., Bardsley, R. G., Buttery, P. J., \& Parr, T. (2010). Tenderness - An enzymatic view. Meat Science, Vol. 84, pp. 248-256. Elsevier.

Koohmaraie, M., \& Geesink, G. H. (2006). Contribution of postmortem muscle biochemistry to the delivery of consistent meat quality with particular focus on the calpain system. Meat Science, 74(1), 34-43.

Locker, R. H., \& Hagyard, C. J. (1963). A cold shortening effect in beef muscles. Journal of the Science of Food and Agriculture, 14(11), 787-793.

Lockley, A. K., Bruce, J. S., Franklin, S. J., \& Bardsley, R. G. (1996). Use of mutagenically separated PCR for the detection of the mutation associated with porcine stress syndrome. Meat science, 43(2), 93-97.

Louis, C. F., Galbrit, E. M., Remple, E., \& Mickelson, J. R. (1990). Malignant hyperthermia and porcine stress syndrome: a tale of two species. Pig News and Information, 11(3), 341-344.

Mahmood, S., Roy, B. C., Larsen, I. L., Aalhus, J. L., Dixon, W. T., \& Bruce, H. L. (2017). Understanding the quality of typical and atypical dark cutting beef from heifers and steers. Meat Science, 133, 75-85.

Matarneh, S. K., Beline, M., de Luz e Silva, S., Shi, H., \& Gerrard, D. E. (2018a). Mitochondrial F1-ATPase extends glycolysis and pH decline in an in vitro model. Meat Science, 137, 8591.

Matarneh, S. K., England, E. M., Scheffler, T. L., \& Gerrard, D. E. (2017a). The Conversion of Muscle to Meat. In Lawrie's Meat Science: Eighth Edition (pp. 159-185). Elsevier.

Matarneh, S. K., England, E. M., Scheffler, T. L., Oliver, E. M., \& Gerrard, D. E. (2015). Net lactate accumulation and low buffering capacity explain low ultimate $\mathrm{pH}$ in the longissimus lumborum of AMPK $\gamma 3$ R200Q mutant pigs. Meat Science, 110, 189-195.

Matarneh, S. K., England, E. M., Scheffler, T. L., Yen, C. N., Wicks, J. C., Shi, H., \& Gerrard, D. E. (2017b). A mitochondrial protein increases glycolytic flux. Meat science, 133, 119125.

Matarneh, S. K., Silva, S. L., \& Gerrard, D. E. (2021a). New Insights in Muscle Biology that Alter Meat Quality.

Matarneh, S. K., Yen, C. N., Bodmer, J., El-Kadi, S. W., \& Gerrard, D. E. (2021b). Mitochondria influence glycolytic and tricarboxylic acid cycle metabolism under postmortem simulating conditions. Meat Science, 172, 108316.

Matarneh, S. K., Yen, C. N., Elgin, J. M., Beline, M., e Silva, S. D. L., Wicks, J. C., ... \& Gerrard, D. E. (2018b). Phosphofructokinase and mitochondria partially explain the high ultimate $\mathrm{pH}$ of broiler pectoralis major muscle. Poultry science, 97(5), 1808-1817. 
McKeith, R. O., King, D. A., Grayson, A. L., Shackelford, S. D., Gehring, K. B., Savell, J. W., \& Wheeler, T. L. (2016). Mitochondrial abundance and efficiency contribute to lean color of dark cutting beef. Meat Science, 116, 165-173.

Molette, C., Rémignon, H., \& Babilé, R. (2003). Maintaining muscles at a high post-mortem temperature induces PSE-like meat in turkey. Meat Science, 63(4), 525-532.

Mulvany, M. J. (1975). Mechanical properties of frog skeletal muscles in iodoacetic acid rigor. The Journal of Physiology, 252(2), 319-334.

Newton, K. G., \& Gill, C. O. (1981). The microbiology of DFD fresh meats: A review. Meat Science, 5(3), 223-232.

Nonneman, D. J., Brown-Brandl, T., Jones, S. A., Wiedmann, R. T., \& Rohrer, G. A. (2012). A defect in dystrophin causes a novel porcine stress syndrome. BMC genomics, 13(1), 1-9.

Norman, J. L., Berg, E. P., Heymann, H., \& Lorenzen, C. L. (2003). Pork loin color relative to sensory and instrumental tenderness and consumer acceptance. Meat Science, 65(2), 927933.

Penny, I. F., Voyle, C. A., \& Lawrie, R. A. (1963). A comparison of freeze-dried beef muscles of high or low ultimate pH. Journal of the Science of Food and Agriculture, 14(8), 535-543.

Pethick, D. W., Cummins, L., Gardner, G. E., Knee, B. W., McDowell, M., McIntyre, B. L., ... \& Warner, W. D. (1999). The regulation by nutrition of glycogen level in the muscle of ruminants. Recent advances in animal nutrition in Australia, 12, 145-151.

Ponnampalam, E. N., Hopkins, D. L., Bruce, H., Li, D., Baldi, G., \& Bekhit, A. E. D. (2017). Causes and contributing factors to "dark cutting" meat: Current trends and future directions: A review. Comprehensive Reviews in Food Science and Food Safety, 16(3), 400-430.

Purslow, P. P., Warner, R. D., Clarke, F. M., \& Hughes, J. M. (2020). Variations in meat colour due to factors other than myoglobin chemistry; a synthesis of recent findings (invited review). Meat Science, 159, 107941.

Qiao, M., Fletcher, D. L., Smith, D. P., \& Northcutt, J. K. (2001). The effect of broiler breast meat color on $\mathrm{pH}$, moisture, water-holding capacity, and emulsification capacity. Poultry science, 80(5), 676-680.

Ramanathan, R., Kiyimba, F., Gonzalez, J., Mafi, G., \& Desilva, U. (2020). Impact of Up- And Downregulation of Metabolites and Mitochondrial Content on $\mathrm{pH}$ and Color of the Longissimus Muscle from Normal-pH and Dark-Cutting Beef. Journal of Agricultural and Food Chemistry, 68(27), 7194-7203.

Ramanathan, R., Mancini, R. A., \& Konda, M. R. (2009). Effects of lactate on beef heart mitochondrial oxygen consumption and muscle darkening. Journal of agricultural and food chemistry, 57(4), 1550-1555.

Rasmussen, A. J., \& Stouffer, J. R. (1996). New method for determination of drip loss in pork 
muscles. Proceedings of the 42nd International Congress of Meat Science and Technology, 286-287.

Ritter, M. J., Ellis, M., Hollis, G. R., McKeith, F. K., Orellana, D. G., Van Genugten, P., ... \& Schlipf, J. M. (2008). Frequency of the HAL-1843 mutation of the ryanodine receptor gene in dead and nonambulatory-noninjured pigs on arrival at the packing plant. Journal of animal science, 86(3), 511-514.

Robergs, R. A., Ghiasvand, F., \& Parker, D. (2004). Biochemistry of exercise-induced metabolic acidosis. American Journal of Physiology-Regulatory, Integrative and Comparative Physiology, 287(3), 502-516.

Rosa, A. F., Fonseca, R., Balieiro, J. C., Poleti, M. D., Domenech-Pérez, K., Farnetani, B., \& Eler, J. (2016). Incidence of DFD meat on Brazilian beef cuts. Meat Science, 112, 132-133.

Savell, J. W., Mueller, S. L., \& Baird, B. E. (2005). The chilling of carcasses. Meat science, 70(3), 449-459.

Scheffler, T. L., \& Gerrard, D. E. (2007). Mechanisms controlling pork quality development: The biochemistry controlling postmortem energy metabolism. Meat Science, 77(1), 7-16.

Scheffler, T. L., Matarneh, S. K., England, E. M., \& Gerrard, D. E. (2015). Mitochondria influence postmortem metabolism and $\mathrm{pH}$ in an in vitro model. Meat science, 110, 118-125.

Scopes, R. K. (1974). Studies with a reconstituted muscle glycolytic system. The rate and extent of glycolysis in simulated post mortem conditions. Biochemical Journal, 142(1), 79-86.

Shange, N., Gouws, P., \& Hoffman, L. C. (2019). Changes in pH, colour and the microbiology of black wildebeest (Connochaetes gnou) longissimus thoracis et lumborum (LTL) muscle with normal and high (DFD) muscle pH. Meat Science, 147, 13-19.

Silva, J. A., Patarata, L., \& Martins, C. (1999). Influence of ultimate $\mathrm{pH}$ on bovine meat tenderness during ageing. Meat Science, 52(4), 453-459.

Suman, S. P., \& Joseph, P. (2013). Myoglobin Chemistry and Meat Color. Annual Review of Food Science and Technology, 4, 79-99.

Swatland, H. J. (2008). How pH causes paleness or darkness in chicken breast meat. Meat Science, 80(2), 396-400.

Tang, J., Faustman, C., Hoagland, T. A., Mancini, R. A., Seyfert, M., \& Hunt, M. C. (2005). Postmortem oxygen consumption by mitochondria and its effects on myoglobin form and stability. Journal of Agricultural and Food Chemistry, 53(4), 1223-1230.

Tarrant, P. V., \& Sherington, J. (1980). An investigation of ultimate $\mathrm{pH}$ in the muscles of commercial beef carcasses. Meat Science, 4(4), 287-297.

Vestergaard, M., Oksbjerg, N., \& Henckel, P. (2000). Influence of feeding intensity, grazing and 
finishing feeding on muscle fibre characteristics and meat colour of semitendinosus, longissimus dorsi and supraspinatus muscles of young bulls. Meat Science, 54(2), 177-185.

Viljoen, H. F., De Kock, H. L., \& Webb, E. C. (2002). Consumer acceptability of dark, firm and dry (DFD) and normal pH beef steaks. Meat Science, 61(2), 181-185.

Warren, C. M., Krzesinski, P. R., \& Greaser, M. L. (2003). Vertical agarose gel electrophoresis and electroblotting of high-molecular-weight protiens. Electrophoresis, 24(11), 1695-1702.

Watanabe, A., Daly, C. C., \& Devine, C. E. (1996). The effects of the ultimate pH of meat on tenderness changes during ageing. Meat Science, 42(1), 67-78.

Wicks, J., Beline, M., Gomez, J. F. M., Luzardo, S., Silva, S. L., \& Gerrard, D. (2019). Muscle Energy Metabolism, Growth, and Meat Quality in Beef Cattle. Agriculture, 9(9), 195.

Wilson, B. W. (1990). Developmental and maturational aspects of inherited avian myopathies. Proceedings of the society for experimental biology and medicine, 194(2), 8796.

Wu, S., Luo, X., Yang, X., Hopkins, D. L., Mao, Y., \& Zhang, Y. (2020). Understanding the development of color and color stability of dark cutting beef based on mitochondrial proteomics. Meat Science, 163, 108046.

Zhang, Y., Qin, L., Mao, Y., Hopkins, D. L., Han, G., Zhu, L., \& Luo, X. (2018). Carbon monoxide packaging shows the same color improvement for dark cutting beef as high oxygen packaging. Meat Science, 137, 153-159. 
APPENDIX: Permission to use article

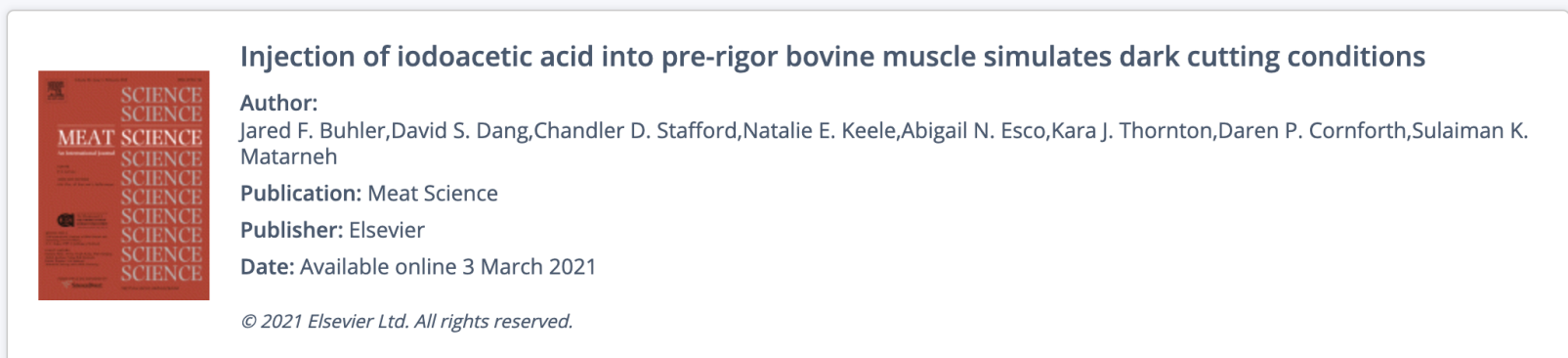

Journal Author Rights

Please note that, as the author of this Elsevier article, you retain the right to include it in a thesis or dissertation, provided it is not published commercially. Permission is not required, but please ensure that you reference the journal as the original source. For more information on this and on your other retained rights, please visit: https://www.elsevier.com/about/our-business/policies/copyright\#Author-rights 